Portland State University

PDXScholar

Dissertations and Theses

Dissertations and Theses

1977

\title{
English Renaissance Humanist Education
}

Lori Ann Bjornstad

Portland State University

Follow this and additional works at: https://pdxscholar.library.pdx.edu/open_access_etds

Part of the European History Commons

Let us know how access to this document benefits you.

\section{Recommended Citation}

Bjornstad, Lori Ann, "English Renaissance Humanist Education" (1977). Dissertations and Theses. Paper 2499.

https://doi.org/10.15760/etd.2496

This Thesis is brought to you for free and open access. It has been accepted for inclusion in Dissertations and Theses by an authorized administrator of PDXScholar. Please contact us if we can make this document more accessible: pdxscholar@pdx.edu. 
AiV ABSTRACT OF THE THESIS OF IOri Ann Bjornstad for: the Master of Arts in History presented 16 November 1977.

Title: English Renajssance Humanist Education.

APPROVED BY MEMBERS OF THE THESIS COMMITTEE:
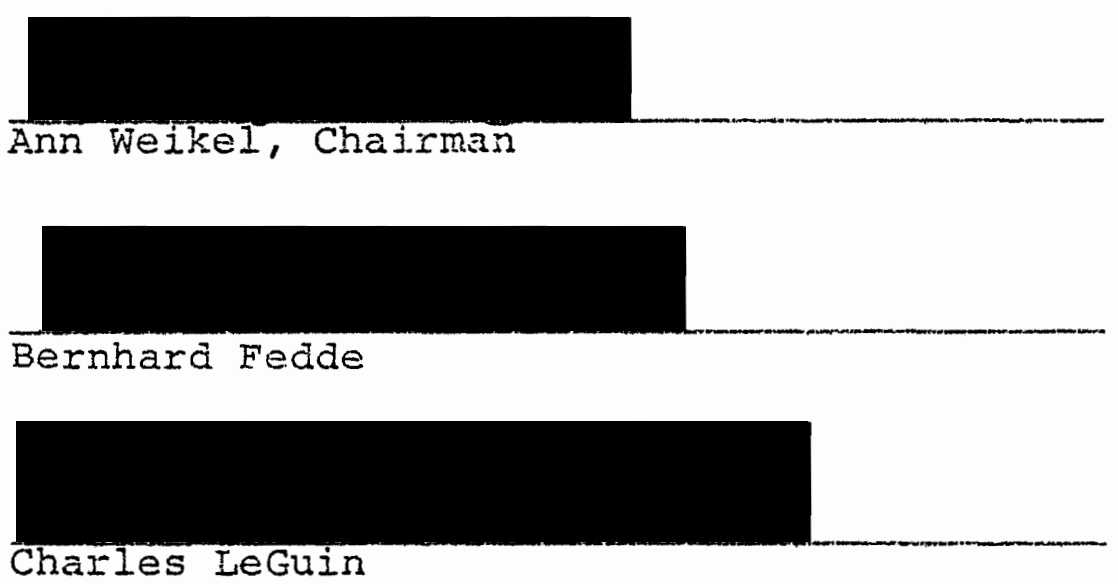

The following examines the historical development of the English education available prior to university entrance in order to discover the impact of humanist ideas on the educaticnal systern. The survey of the structure and theory of preuniversity English education begins in the aarty Middle Ages and continues through the Elizabethan period. After examining the Medievai background, there foliows a discussion of the political and religious settlement of the Reformation, and the basic programme of the humanist reformers. Individual muanist writers are then studied, followed by a discussion of schools plamned on humanist 
lines. With this, however, is contrasted a picture of English Renaissance schools in reality.

Many sources were consulted for background material as well as for specialized data on specific humanist writers. Primary sources were consulted whenever possible, but more often, it was neccesary to use secondary sources which examine primary sources. The Columbia Teachers College Series on the history of education was exceedingly helpful in this regard.

The conclusions drawn are as follows. In spite of political changes and the influx of many new ideas, the English educational system remained very much the same from the Middle Ages through the reign of Elizabeth. However, humanist ideas remained popular and influenced educational thought in the years that followed. 
ENGLISH RENAISSANCE HUMANIST EDUCATION

By

Lori Ann Bjornstad

Thesis submitted in partial fulfillment of the requirements for the degree of

MASTER OF ART

IN

HISTORY

Portland State University

1977 
TO THE OFFICE OF GRADUATE STUDIES AND RESEARCH:

The members of the Committee approve the thesis of Lori Ann Bjornstad presented 16 November 1977.

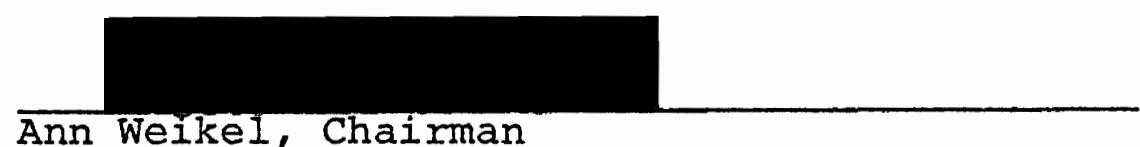

$$
\text { Ann Weikel, Chairman }
$$

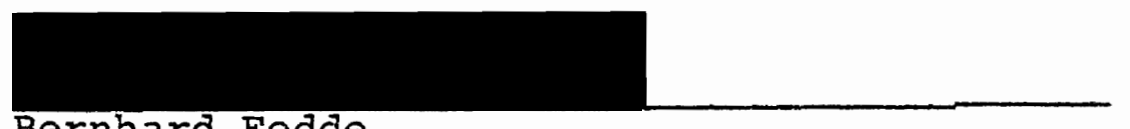

Bernhard Fedde

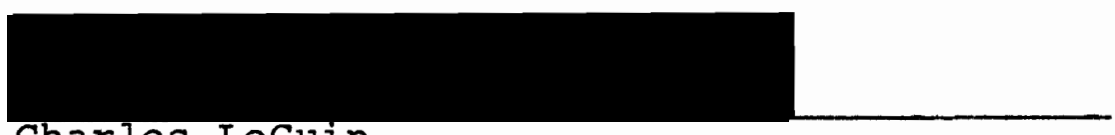

APPROVED:

Michael Reardon, Head, Department of History

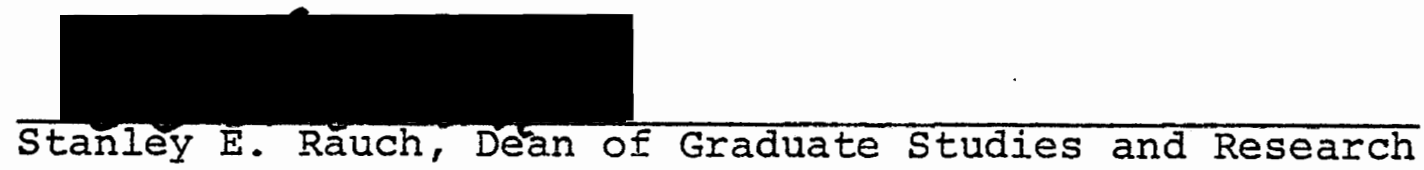




\section{ACKNOWLEDGMENT}

\section{TO MARK}

Without whose encouragement this work would not have been accomplished. 
TABLE OF CONTENTS

ACKNOWLEDGMENTS . . . . . . . . . . . . . iii Chapter $\underline{\text { Page }}$ Introduction . . . . . . . . . . . . . I

II The Structural Background . . . . . . 6 III The Reformation Settlement . . . . . 20 IV The Educational Program . . . . . . . 29

$\checkmark \quad$ The Major Humanists: Erasmus . . . . . 35

VI The Major Humanists: Vives . . . . . . 44 VII The Major Humanists: More . . . . . . 54 VIII The Minor Humanists . . . . . . . 61 IX The Humanist Schools in Theory and Practice . . . . . . . . . 81

X English Renaissance Schools in Reality . . 94 XI Conclusion .............. 101 Bibliography - Primary Sources . . . . 103 Bibliography - Secondary Sources . . . . 104 


\section{CHAPTER I}

\section{INTRODUCIION}

A culture's educational practices and theories play a great part in determining how that culture will be viewed by others. To the Renaissance man, the ancient cultures of Greece and Rome were an ideal, and the thousand years between the fall of the western Roman Empire and their age were little more than a cultural wasteland, a period of transition from one age of ideal culture to the true revival of civilization in the Renaissance.

It might have seemed to the fifteenth century intellectual that for centuries educational advance was hopelessly retarded by endless commentaries on obscure points of grammar, commentaries on Aristotle and other ancient authors and, indeed, commentaries on commentaries. Writings of the classical cultures were available through Arabic translations to fifteenth century Europe, and an attempt was made to revive the best of the ancient civilizations. Latin, Greek and Hebrew were studied in their classical forms, and old ideas were adopted and adapted to the fifteenth century worla.

The obvious way to spread classical learning was through education. The first step was to move away from the scholasticism of the Middle Ages toward Iiterary studies. Those who championed this new approach became known as humanists. The humanist program of education was spread 
throughout Europe and to England by traveling scholars and their correspondence.

The intent of this work is to show how educational theory below the university level in England changed with the advent of humanist ideas. To accomplish this task, it will be necessary to examine briefly the basic structure and theory of the Medieval educational system. I This background will be contrasted with English Renaissance theory and practice. The study will show that although humanist educational ideas became widespread in intellectual circles,

${ }^{1}$ Some of the terms used in discussing medieval education have connotations significantly different from today's usage:

School Generally today this means the building where classes are held. In the Middle Ages, however, the building was accidental, specific buildings being a late development. Etymologically, "school" means leisure, the idea being that leisure time was used for discussion. A second stage of development is when the term is restricted to organized school, meaning a master and his scholars, the place still being unimportant.

Grammar This term came to denote the study of the Latin language, but included much more than learning vocabulary, parts of speech and sentence structure. Latin authors were read for practice, of course, but also of great importance was style and historical, moral and literary content. The term "grammar school" came to denote an organized teaching of Latin.

Free This epithet usually accompanies "gramnar school." It does not indicate that fees were not charged or that the school was independent of the church, but that the schools were open. to all, regardless of social standing.

Parry, A. W., Education in England in the Midale Ages, Lonaon: W. B. Cilive, 1920, pages 63-75. 
in practice change was slow in coming. The major reason. for failure was the general lack of properly trained teachers. Those who were qualified to teach on humanist lines sought better paying positions than those available in the teaching profession and this tended to keep the educational system from advancing as quickly as many humanists would have preferred.

Many sources are available to the student interested in education of this particular period of history. Especially helpful in this study were Simon's Education and Society in Tudor England, and Orme's English Schools in the Middle Ages. These two works provided valuable background material. Charlton's Education in Renaissance England also proved to be valuable for background information and was of benefit also because it dealt with a more specific time and subject matter.

As one gets into more specialized research, the books by W. K. Jordan are very useful. Philanthropy in England 1480-1660 provided valuable statistical documentation of the amounts and types of charity given by each social group over a specific time period. Another of Jordan's books, Edward VI: The Threshold of Power, presents a more controversial view of the historical problem of the Chantries Act of 1547. Jordan disagrees with the typical view of the spoilation of the chantries, and his input is valuable in understanding the question in its entirety. 
Three Primers Put Forth in the Reign of Henry VIII

proved to be a disappointing primary source. The three primers contained little besides prayers and were of little use for this study. However, two secondary sources (which might, based on their titles, appear to be primary sources,) turned out to be very helpful. McDonnell's Annals of St. Paul's School does not contain the statutes as set out by colet, nor are the statutes even discussed in the book. Instead, MCDonnell has presented a history of st. Paul's through discussion of each highmaster and many of the ushers. The book proved to be a valuable source but regrettably did not contain the statutes. The other source referred to is Nelson's A Fifteenth Century Schoolbook. This is not a reproduction of an old grammar book, but is a compilation of many old grammar books with examples of sentences used for translation and descriptive comments by Nelson on methods of teaching.

There is a definite lack of sources concerning medieval educational theory below the university level, and the work by Jarrett, Social Theories of the Middle Ages, 1200-1500, is not rich in information on educational theory. This lack of sources is due mainly to the dearth of evidence from Medieval educators concerning the theories of their day. It is entirely possible that teaching methods were not subject to a great deal of theorizing in the Middle Ages, as was the subject of grammar, and that youth were taught in the only 
way possible, considering the scarcity of books and other tools. In addition, the available body of knowledqe was not as great during the Middle Ages as it became at a later period, and fewer people were educated, factors which go far to explain the lack of need to develop various theories of educational methods.

Because of the breadth of the subject, university education has been omitted from the scope of this work. Instead, the study will focus on the structure and theory of the education available to the various social classes prior to university entrance. Volumes have been written on Medieval and Renaissance university lefrning as well as the changing ideas during the transition from Medieval to Renaissance thought, and the subjecty cannot be adequately covered in a few pages. 


\section{THE STRUCTURAL BACKGROUND}

The roots of the English educational system are found in the early Middle Ages. At this time, the primary educational stimulus came from the Church, as few besides aspiring churchmen sought an education. Even had the demand been greater, the monastic establishments which provided clerical education would have been able to serve only a limited number.

Realizing these problems, Dunstan, a leader of monastic reform in the ninth century, set out to stimulate local parish priests to do their duty toward education. To that end, Dunstan, as Archbishop of Canterbury, began to enforce certain canons promulgated in 797 at a diocesan synod, which stated that every Christian man was to "zealously accustom his children to Christianity and teach them the Pater Noster and creed," including as well instructions to priests to "diligently teach youth and educate them in crafts that they may have ecclesiastical support." 2

It is impossible to estimate the extent to which these canons were complied. The Domesday Book (1086) is the great authority for the social condition of the post-Conquest period and it provides evidence that there was at that time provision for education in various parishes. ${ }^{3}$ There is,

\footnotetext{
2 Ibid, pages $33-38$.

3 Ibic, page 41 .
} 
however, at least a century between the enactment by Dunstan (late loth century) and the evidence of Domesday Book. The Viking invasions and other events which took place during the intervening period had an impact on education, making it difficult to assess the impact of Dunstan's reforms.

The Norman Conquest, through its religious contributions, had a significant impact on the educational development of England. The Normans brought the English church into closer contact with the Church on the continent and with william's appointment of able and energetic men from the continental monastic intellectual centers, such as Lanfranc and Anselm of Bec, to the chief administrative posts, the Church gained new life and a new direction.' This stimulation of church activities required more literate men, and an organized system of education emerged, consisting of the establishment of schools of theology in connection with cathedral churches, the establishment of grammar schools and song schools in connection with collegiate and parochial churches, and the recognition of the chancellor of the cathedral as the head of the educational program of the diocese.

The attempt to expand the educational facilities available through the church was directed largely toward the segment of society destined for an ecclesiastical life, i.e. the younger sons of the nobility and sons of the poor. Medieval education was generally geared to utility, and the nobility, who would be in positions later to hive a clerk for literate duties had no need to seek formal schooling. 
The clerical life, however, involving the understanding of clerical texts and the Bible, necessitated literacy.

As a general rule, schools existed in connection with every large monastery. These were either founded by the monastery itself, or were endowed by pious benefactors, with the monks as trustees. Another type of school often kept by monasteries was supported by alms (Almonry School). The schools were attended by young boys who provided music for divine services in exchange for being maintained and educated by the monks.

The quality of education received in monastic schools was generally as good as in the grammar schools taught by the secular clergy, and the curricula probably did not vary much between the two types of schools. Indeed, the importance of the schools of the religious orders cannot be doubted. The greatest service of monastic schools to general education was in supplying learned monks to the episcopate where as bishops they were well-equipped to teach the youth of their households. In all such schools, the teaching depended on the learning and capacity of the bishop, priest or monk. 4

With the growth of universities as centers of theological learning in the 12 th and 13 th centuries, many monks began to acquire advanced degrees in theology, yet the common parish priest was not a Doctor of Theology. Indeed, the ideal situation envisioned by the bishops did not exist, for some

${ }^{4}$ Artz, Frederick B., The Mind of the Middle Ages, A.D. 200-1500, New York: Alfred A. Kropg, 1966, page 306 . 
priests were barely literate, if not illiterate, and ignorant of even the most elementary religious liturgy. The Bishops, trying to establish a high standard of learning among the clergy, were aided by a system of checks which had existed in the ordination process since the early church. As ordination was administered in several stages, there were several opportunities for the church to examine the candidates. Should the candidate prove to be insufficientiy educated, he was instructed to obtain further education. ${ }^{5}$ In this manner, an attempt was made by ordaining bishops to establish a high standard of learning among the clergy, but their attempts were often frustrated. As a clerical benefice could be a position of wealth eagerly sought by younger sons or relatives of nobles, bishops were often under a great deal of pressure to grant benefices to the person chosen by an influential noble. This placed in jeopardy the aim of upgrading the clergy by selective appointments to benefices, and though a bishop might try to withstand it, the pressure applied by their social superiors was usually too great. The social position of the nobility prevented them from taking part in the free education of the church which others accepted. Instead, the elder sons of noble parents were sent to the great households, a custom well established by the tenth century and continuing through the Middle Ages. The great households trained the young nobles with the

50rme, Nicholas, English Schools in the Mj.ddle Ages, London: Methuen and Company, Lta., 1973, pages 14-21. 
knowledge, skill, habits and qualities of the "Perfect Knight." The ideals of chivalry, to which every knight was expected to ascribe included military prowess, service and loyalty to one lord, the "worship" of women, and religious dedication, demonstrated through pilgrimages and the crusades.

During the first seven years of preparation for knighthood, the young aspirants were pages, performing the most humble domestic duties and practicing everything they saw the knights do. At the age of fourteen, the page became a squire, whereupon the training became more severe and included the art of warfare, as well as duties in connection with the stables and horses, and skill in the art of heraldry. Intellectually, the young men were given instruction in language (reading and speaking Latin, French and possibly Italian), and taught to sing, pipe, dance and play the harp. The custom of sending boys of good families away to great households contributed to the practice of sending boys to residential schools in modern times. Some of the ideals of chivalry have lived on, such as the admiration of physicai prowess, and fagging (the ideal of loyalty). Chivalry was not a perfect discipline, but it did encourage obedience to rule, service to the church, good faith, unselfishness and courtesy. However, against these virtues must be balanced the vices of ostentation, love of bloodshed, contempt of inferiors, and loose manners. Even so, the code of chivalry served an important purpose for the society in which it was found. 
The concern for literacy was shared by the lower classes, but to a less ambitious degree and for different reasons. As the apprenticeship system became well established in the towns, controls were placed on the number of apprentices and the conditions binding them. By the fifteenth century, entrants to the better trades were expected to have a reasonable standard of education which stimulated the demands for a different type of education than offered by a parish clerk or chantry priest. It was at this time that the craft gilds and towns began to endow schools. 6 Many people who were entering trades were less interested in the complete literary and linguistic curriculum offered by the grammar schools than in the practical use as applied to the administrative and commercial spheres of life.

To satisfy the needs of such people, there evolved in the later Middle Ages a class of schoolmasters who specialized in the more practical aspects of Latin, mainly that of composing letters, formal or informal, as well as drafting deeds and charters. This class of schoolmasters also dealt with some areas not strictly grammatical, such as iegal records, and the keeping of accounts. Thus, in time, business studies became a definite subdivision of English education.

The chief center for business study in the Midale Ages was Oxford, going back to the time of King John. A number of masters gave instruction in dictamen, accounting, French

${ }^{6}$ Simon, Joan, Education and Society in Tudor England, Cambridge: at the University press, 1967, pages 14-15. 
and the principles of Common Law. While these courses were not a part of study for any degree, their existence reflects the popularity of oxford for students of all kinds, from those seeking a specialized course of study, such as theology or medicine, to those who desired more general, practical learning.

The opportunity for education for the lower agricultural class was limited. Villeins could not send their sons to school without first purchasing, in the form of a license, the permission of the Lord. The restriction was not intended to keep them illiterate, since their literacy would have done no harm, but schooling presupposed a career in the church or in a trade or profession, hence leaving the manor. The license required from the Lord was sometimes granted for only a limited period of schooling, the Lord retaining the option to either free the villein if he made good progress and went on to become a clerk or to regain control over him and return him to the land.

The whole trend of Medieval thought was against the learned woman. Her role was social and economic, not literary or scholastic. Even in the Benedictine order, which provided a higher standard of education than was available to most women, writing was considered to be outside the scope of the concerns of women. No nunnery produced a chronicle, and while nuns were expected to be literate, most knew no Latin. 
While nunneries are often considered to be the primary source of education for women in the Middle Ages, there is little evidence for this assumption. While it was a fairly general custom among English nuns to take girls (and sometimes boys) for education, there are four limitations within which this conclusion is true. 7 First, not all nunneries took children, and those which did seldom had large schools. About two-thirds of the nunneries took girls for education, and the largest number recorded at one time in one establishment is twenty-six. Most nunneries were very small, so the number of children they could handle was correspondingly small. Second, the children who were educated in the nunneries were drawn exclusively from upper and wealthy middle-class families. Only girls who could pay their own way were accepted into nunneries; for they were generally very poor establishnents, and the reception of school children was essentialiy a financial expedient. Third, the practice was at first forbidden and later restricted by the Bishop, who regarded it as subversive of discipline. Although the attempt by bishops to restrict the admission of children was ignored by the nuns, maximum age restrictions were placed on students, from five to eight for boys and twelve to fourteen for girls. Fourth, the education received by the children was scanty, limited by the capabilities of the nuns, and not of the highest order. Latin generally could not be taught 
because most nuns did not know Latin, so the education of the children was limited to learning by rote to say the Ave, Pater Noster and the Creed, and possibly to read in the vernacular.

The nunneries were not finishing schools for girls; evidence shows that they learned little besides a very elementary education and piety. Those girls who did not learn their letters in nunneries probably picked them up informally from parish priests or other literates, or in public elementary schools.

For those children who were not sent to great households or ecclesiastical schools, the public elementary school might be the first place of formal education. 8 Here they learned the $A B C$ 's and other rudiments of education, both secular and ecclesiastical. Methods of instruction varied, the alphabet sometimes being written in black on the whitewashed walls of the classroom. Another method, which carried over to the eighteenth century was the hornbook, which consisted of large letters fixed to a piece of wood, later on covered with with a transparent piece of horn. A third method of teaching the alphabet was the primer. This was a religious miscellany containing the basjc prayers and elements of the faith and the more simple liturgical devotions for the laity. It often began with an alphabet, thus serving as the basic textbook of elementary education.

${ }^{8}$ Orme, op. cit., pages $60-63$. 
Grammar schools formed the second tier in the system of education. The study of grammar can be traced back to classical times, and there existed a large body of works dealing with the theoretical and practical sides of grammar which even in the later Middle Ages scholars were seeking to improve and popularize. The study of grammar at this stage involved correct spelling and pronunciation, the mastery of the basic inflections and construction, and the assimilation of vocabulary. The two most popular grammar texts were Ars Grammatica written in the mid fourth century by Donat, and Prician's Institutiones Grammatical, from the sixth century. ${ }^{9}$ Teachers of grammar dealt with both the Latin language and literature, and tried to impart the ability to read, write, speak and understand the Latin language. At what age were children sent to school? In the sixteenth century, many theories about the proper age to begin a child's education were discussed by the educational writers of the northern Renaissance and most followed Quintilian, settling on the age of seven. This was probably the Medieval practice as well. 10 A child was first sent to elementary school to learn the basics, and then to grammar school, at any age between nine and twelve. The age varied according to the ability of the pupil, the interest and resources of the parents, and the existence of suitable schools.

9 Parry, op. cit., pages 65-67.

10 orme, op. cit., pages 60-63. 
Tuition fees affected almost everyone as free places in schools did not begin to appear until the fourteenth century, and while free schools were founded in the fifteenth and sixteenth centuries, this was by no means universal, even by the Reformation. In addition to tuition, bondsmen had the expense of paying fees to the lord for permission to send their sons to school. If the student was sent away for his education, he also had the expense of board and lodging. Some schoolmasters took in boarders, as did private householders, yet the costs were still high. In addition, all students would have miscellaneous associated costs for suitable clothing, pens and ink, candles, and sometimes books.

The number of years a student spent in the grammar schools varied with the intended goal. A clerk planning to take Holy Orders, to go to the university, or to join a monastic order would probably attend grammar school for five or six years. Likewise, a young noble, it he were educated at schools of this sort, might attend for six years. Yet for a tradesman or other young man seeking only the basics in grammar, two or three years might suffice before going on to learn a trade. Education was nicely flexible; a person was able to obtain as much or as little as he wanted. For many centuries during the Middle Ages, the church had a monopoly on education, a monopoly which was broken when the demand for regular schooling began to outdistance 
the supply of available teachers. In theory, the church was to provide a free education to all while in practice, fees were universally charged for instruction in the grammar schools and for granting teaching licenses to other masters. These other masters began to stress the harm done by the Church's monopoly on teaching and sought remedy through the secular courts. The issue was mainly fought out in London, where the population was rising rapidly and masters set up to teach Latin grammar without seeking a license from one of the three ancient foundations (St. Paul's, St. Mary Arches, and st. Martin le Grand ${ }^{11}$, which held the monopoly in the city. With the common Law on the side of the laity, the lay demand for education began to be met in the late fifteenth century, often at the direct expense of the church.

Although little is known about theories of education in the Midale Ages, information on the conditions which existed is available and does shed some light on theory. Life inside the grammar school was often not a happy one. The classes were generally large, and necessarily so, for at 8 d. per quarter, a schoolmaster would need forty students to earn 15 per year.12 To add to their difficulties, masters were faced with controling large classes for very long hours. To take full advantage of available daylight, classes often began at 6:00 A.M. and lasted until 5:00 or 6:00 P.M., with one or two hours off each for breakfast and Iunch.

11 orme, op. ait., page 169.

12 Ibid, page 121. 
Faced with such problems, it is easy to imagine that discipline would sometimes be difficult to maintain. Masters were often driven to the liberal use of the rod, yet it must not be imagined that schoolmasters had a monopoly on cruelty. They exercised the same authority in school that parents exercised at home. Beating was socially established as the proper method of preserving family discipline and inculcating obedience, industry and virtue. By the fifteenth century, some educators were aware that moderation in beating was desirable. Wykeham's statutes for Winchester in 1400 instructed his headmaster to punish his pupils in moderation: Thomas Beckington, Bishop of Bath and Wells, instructed in his statutes of 1459 that boys who refused to learn their lessons were first to be warned kindly, secondly if they neglected these warnings were to be sharply rebuked, and thirdly, if necessity arose, were to be flogged. The student had few real breaks in his education as Medieval schools were in almost continuous session throughout the year. There were many holidays, however, generally coinciding with the great festival days. The boys often remained at school and sometimes even did lessons during the long holiday periods such as Christrnas, Easter and Whitsuntide. The holiday when the students generally went home was a three week intermission lasting from Ascension Day to Corpus Christi. 
It can be seen that the English Medieval Educational system was not a highly organized network of schools with universal standards of educational quality or even curricula. Changes in the English educational system brought about by the Reformation and Renaissance will be dealt with in the following chapters. It will be shown, however, that in spite of social and political changes and an influx of Humanist reforming ideas, many basic features of English grammar schools, such as discipline, and methods of teaching remained constant. 


\section{THE REFORMATION SETTIEMENT}

Each historian might express a different view as to when the Middle Ages gave way to the Renaissance. From the standpoint of educational theory, the end of the Middle Ages in England can be placed at about 1520 as the curriculum changed into that of the Renaissance. As institutions, however, Medieval schools did not change until the 1530's and $40^{\prime} \mathrm{s}$, as a consequence of the Reformation.

The dissolution of the monasteries begun by Henry VIII in 1536 had a significant impact upon education. The schools affected by this action, were in two broad categories: those schools held in almonries and belonging directly to the monastic establishment, and those schools held in trust by the monastery for an outside benefactor. The immediate effect of the 1536 dissolution was the cessation of recruitment to the monasteries and the falling away of recruitment to the church, whose benefices were no longer attractive financially. A more lasting effect of the 1536 enactment was that many useful places of education disappeared for which substitutes were needed.

Between 1536 and 1540, some 500. houses of monks and canons were dissolved by Henry VIII. It is not possible to make an accurate estimation of the loss to education, as we lack much of the necessary information about how many houses maintained schools, how many students were kept, and so 
on. ${ }^{13}$ Nevertheless, there must have been some Ioss, for the opportunities for upper-class boarding education were reduced.

However, as a direct result of the Dissolution, several schools were established or re-established. By an Act of 1540, all eight monastic cathedrals were reconstituted as secular foundations like York, Lincoln, or Salisbury, having a dean and chapter of canons instead of a prior and convent of monks. In each of these "cathedrals of the new foundation" a grammar school was made an integral part of the establishment. In addition, six of the greater dissolved abbeys - Bristol, Chester, Gloucester, Oxford, Peterborough and Westminster - were elevated to cathedral rank in 1540-42, serving new dioceses. With the exception of oxford, which was already served by Magdalen College School, the chapters of these new cathedrals were required to establish a grammar school. It might be argued, therefore, that on balance schooling gained rather than lost through the Dissolution. 14

The Chantries Act of 1547 had even greater implications for English education. After 1540, there were no longer monastic establishments on which to lavish penitential money, and wealthy citizens increasingly endowed or refounded chantries with schools attached. The Chantries Act vested in the crown all possessions of colleges, free chapels,

13 Lawson, John, Medieval Education and the Reformation, London: Routledge and Kegan Paul, Ltd., 1967, page 71 . 
and chantries (except those dissolved by their patrons five or more years before) and all fraternities, brotherhoods and gilds other than fellowships of mysteries or crafts.

The intent of the Act was to put down popish superstitions and to use the money gained from these endowments to establish schools controlled by the government through borough or lay governing bodies. Attention was concentrated to the end of establishing one or two good schools, usually with two reasonably well-paid masters apiece, in each county. Edward VI's advisors, procrastinated about the refoundations, for by 1549 , only three schools had been founded and confiscated lands were fast being sold. Yet, according to Jordan, the idea of the Edwardian spoilation of the chantry schools is a myth. 15

In 1549, a bill was introduced "for making schools and giving lands thereto." 16 The bill was allowed to languish in committee after three readings in commons and one in Lords, probably because of further assurances by the government that existing chantry schools were not to be touched. There was a danger, somerset and the King were told, that chantry wealth would be distributed as irresponsibly as was the monastic Iand. In fact, the Chantry Commissioners were scrupulous in their efforts to protect and conserve all the charitable uses to which the chantry wealth had been dedicated. The government was carefully following a policy of preserving

${ }^{15}$ Jordan, W. K., Edward VI: The Threshold of Power, Cambridge: Harvard University Press, 1970, page 227-228. ${ }^{16}$ Ibia. 
existing schools, but could not afford to draw on the chantry wealth now in hand for the substantial enlargement and support of local chantries, and particularly for the founding of many wholly new grammar schools. From this failure, and from the abusive condemnation received from contemporary critics, the myth of the spoilation of the existing chantry schools has sprung and persisted.

What generally happened was that most of the schools which were legally part of a foundation, and thus covered by the Act, were continued by warrants issued as early as July 1548.17 some of the schools were put on a sounder footing by the actions of local inhabitants, anxious to safeguard their school. Further, after 1551, when the government's worst crisis had passed, many towns petitioned for the refoundation of the local school under municipal trusteeship with a grant of former church lands. These are the socalled King Edward VI grammar schools, a few refounded by Act of Parliament and others by letters Patent.

Of course many schools were unaffected by the Chantries Act. Specifically excluded were the colleges at Eton, Winchester, Oxford, and Cambridge, and all cathedral chapters. Also untouched by the Edwardian dissolutions were those schools which existed independently of any religious foundation, being under the trusteeship of town corporations or having their own governing bodies. Moreover, the number

17 Lawson, op. cit., page 77. 
of private teachers increased because dispossessed and unpensioned chantry priests were driven to keep schools in order to make a living.

Thus, the Act of Edward VI caused some dislocation of schools but no wholesale closures. In general, the schools refounded during the reign of Edward VI mark a new departure in education. Following on what had been virtually a national survey of school provision, the schools were conceived of as part of a unified educational system serving a Protestant nation. 18

During the second half of the sixteenth century, the most marked feature of the economic and social history of the English midlands was the rise of the substantial yeoman farmer, who now began to figure in the founding of schools. Not only in market towns, but in the more populous villages, schools were established in response to increasing lay demand. With commerce expanding, professions taking shape and the church on a new footing, education was becoming the key to advancement in many fields.

The increase in the number of new grammar schools has been statistically documented by W. K. Jordan. His research shows that although the foundation of grammar schools went on a varying rates of increase between 1480 and 1660 , the rate of increase was especially rapid between 1550 and 1640 when private charity produced an enormous expansion of grammar-school education. The chief weakness in his argu- 
ment is his failure to adjust his figures of bequests and donations to the changes in monetary values during this inflationary period. His main thesis, however, must be accepted: an increase in schools went on during the Tudor period and the dissolution of monasteries and chantries had no appreciable effect on the general trend. 19

According to Jordan's analysis, all social classes contributed to the foundation or endowment of gramuar schools, but those principally responsible for the endowments were the gentry, clergy, and most of all the merchants. In all, doners between 1480 and 1660

gave the immense total of $1448,8998 \mathrm{~s}$. For the creation of a national system of education in England. Beginning with the meagre resources from the Medieval past, these men had greatly extended the whole range or opportunity for aspiring youths and had established educational resources which were on balance not to be substantially improved for all of two centuries. 20

When the reign of Edward is given its due weight as a period of educational advance, that of Elizabeth falls into place as a conservative age. After the reign of the Catholic Mary, the promotion of education to ensure unity in religion and consolidation of the social order was a continuing concern. Politically, it was necessary to pursue the unity of religion at the expense of the more radical educational reformers.

${ }^{19}$ Lawson, op. cit., pages 81-82.

20 Jordan, W. K., Philanthropy in England, 1480-1660, New York: Russell Sage Foundation, 1959, page 289. 
The importance of capturing the minds of the young in order to advance Protestantism was recognized by many leading reformers on the continent. In England, too, the schoolmaster was seen by the authorities as a most valuable ally in promoting the new Elizabethan settlement, or alternately, as a potentially dangerous threat against it. The main instrument of control was the episcopal license. The license was a medieval instrument, but no mention of it is made in the Reformation context until the reign of Mary, when her injunctions to the bishops in 1553 ordexed them to "examine all schoolmasters and teachers of children and, finding them suspect in any waỳs, to remove them and place catholic men in their rooms."2l This, the general policy of Mary's reign, was intended to ensure that schoolmasters who were in favor of reform were driven out of their schools and replaced by Catholics.

In Elizabeth's reign, the episcopal license became the means to enforcing the new Anglican settlement in the schools. The Queen's injunctions of 1559, forbade any man to teach without the bishop's license, granted after being examined for his "learning and dexterity in teaching, as for sober and honest conversation, and also for right understanding of God's true religion."22 A "right understanding of God's true religion" could only mean acceptance of the Elizabethan settlement.

$21_{\text {Wood, Norman, The Reformation and EngIish Education, }}$ London: George koutledge \& Sons, Ltd., 1931, page 54 . 
In addition to the doctrinal conformity imposed on schoolmasters, uniform religious training was enforced on schools to secure the new Establishment. This chiefly took the form of authorized manuals of instruction, the Primer for young children, which contained basic prayers (first issued in 1555) and the Catechism for older ones, (the first issued in 1553 at Edward VI's command). The uniformity of religious instruction was reinforced by the compulsory use of the Royal Grammar. As early as 1529 a commission of churchmen had been appointed to recommend a standard method of grammar teaching based upon a single text. They chose the Latin grammar compiled c. 1515 by William Lily and Erasmus for St. Paul's school, and the sole use of this book was commanded by Henry VIII in 1542 .

Compulsory Bible study and church attendance were added to the compulsory teaching of the Catechism. The injunctions of 1559 ordered all teachers of children to "stir and move them to love and do reverence to God's true religion now truly set forth by public authority" and by having them learn "such sentences of scripture as shall be most expedient to induce them to all godliness." 23

In these various ways, church and state endeavored to regulate the schools in the interests of religious uniformity. By the 1570's, every bishop on his visitation wanted to know if the local schoolmaster was duly licensed; if he taught the authorized grammar and catechism and appropriate sen- 
tences of scripture, if he attended Holy Communion and took his scholars to church at sermon time. Under this surveillance, the grammar schools must have played a significant part in achieving the transition of England from Catholicism to Protestantism in the short space of three or four decades. 
CHAPTER IV

THE EDUCATIONAL PROGRAM

In England, the traditional Medieval outlook on education lasted almost unchallenged until the sixteenth century. The scholastic argument in favor of education starts with the assumption, which underlies so much of medieval reasoning, that man always seeks happiness, and that he is driven by the impulse to find happiness. 24 Every faculty of man - intellectual, moral and material - had this thrust for happiness, and true happiness was achieved only when the three faculties were satisfied. Thus, the development of these three faculties each deserved a place in the education of man.

The importance of education in the thirteenth century was not to impart a great amount of correct knowledge, but the quickness of intellect, which logic or dialectic would bring. The purpose of the training consisted principally in teaching accuracy of word and thought and swiftness in argument, aimed at producing the ready speaker, not the learned man. Learning came to be the pursuit of scholars, but the object of education was to sharpen the wit.

From a practical standpoint, education was esteemed for the employment it could bring. Having a position such as a clerkship in a Medieval government might have conferred

24 Jarrett, Bede O. P., Social Theories of the Middie Ages, 1200-1500, Longon: Ernest Bern Limited, 1926, page 33. 
esteem, but did not end in being titled, for the English held to the traditional belief that honor and title depended on a long lineage. Yet, by the late fifteenth century, there had developed among English kings the practice of rewarding good service to the crown with advancement in the church or by conferring noble rank. This was often at the expense of the nobles who traditionally expected to hold the high ecclesiastical positions, and who deeply resented "upstarts." Under these circumstances, the traditional view of nobility became increasingly outdated and it became more and more clear that the right kind of education could contribute much to a successful career and social advancement. Unfortunately, that kind of education was less available to the nobles than to men of lesser rank.

The general view of education had been changing because of another important influence: Renaissance Humanism. For the purpose of this study, the term "humanist" is applied to scholars who championed literary against scholastic studies, rhetoric and declamation against logic and disputation. Humanist writers helped to pioneer a new outlook by advocating a new approach to and methods of learning which in time became the general trend in intellectual exchange and production. The humanist ideal indicates an outlook on learning generally and the relation of learning to life which, in tune with social developments, was seen to hold the key to the future. 
The origins of Italian humanism seem to be connected with the growth of towns and the revived study of Roman law. The rise of an urban civilization in Italy and the revival of the study of Roman law which it brought about made the study of the past more vital, and a more live and contemporary isste. In the course of study, the Italian legal profession began to sense the distance which had developed between the civilization of the classical past and their own time. Thus, the earliest Italian humanism (fourteenth century) was not initially a scholarly reaction against scholasticism, or a desire to restore ancient culture, but a spontaneous and natural interest in Roman civilization. However, as humanist ideas spread and evolved, the emphasis changed to a reaction against scholasticism, and the desire to restore the best of Roman civilization. 25

The Golden Age of English humanism is generally regarded as the time of Erasmus, More, Colet and their contemporaries. However, English scholars had been exposed to humanist ideas before the early sixteenth century. Many contacts between northern and Italian scholars were made during the Courcils of Constance (1414-1418) and Basel (1431). In addition, English students had for many years made the journey to Italy, especially to study Canon and Civil law. During the fifteenth century, there were humanist circles in nearly all of the larger cities and in the university towns.

25Artz, op. Cit., pages 435-440. 
The original humanist thrust in England was directed toward religion and ecclesiastical reform and spread naturally to lay education. The most important step was to learn the classical languages of Greek, and especially Latin. Fluency in these tongues would open the gate to the greatest body of knowledge available, that of ancient writers and scripture. In order to eliminate the prevailing condition of lack of learning, worldiiness and corruption in the church, there must be a return to the study of the Bible and the early church fathers.

Erasmus, the foremost spokesman of humanism in England, was very interested in moral and religious reform. ${ }^{26} \mathrm{He}$ insisted that theologians be sound grammarians, for scripture could not be interpreted by divine inspiration, but only by solid learning. To that end, Erasmus set himself a number of tasks, including the clarification of certain points of grammar which had been drawn into the orbit of scholastic dispute and studying the languages in which the scriptures had originally been wxitten, notably Greek. In addition, in 1516, Erasmus made a new Latin translation of the New Testament. His translation showed that many passages in the Vulgate were a bad rendering of the original Greek or were manifestly corrupted. This was seen as a fundamental challenge to the authority of the church.

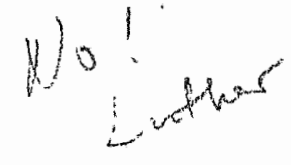

${ }^{26}$ Ibid, page 441. 
The idea of a European Community of states welded together by a common language, learning and creed was central to humanist thought. Their criticisms of monasticism, the worship of saints and relics and pilgrimages to shrines, the constant exposure of abuse of ecclesiastical power and neglect of charitable duties paved the way for more thoroughgoing reformers. This was especially true in their call for the spread of Christian education in the vernacular. The humanists stressed the need to spread education so that ordinary men and women might have access to the scriptures in their native tongue. In the humanist view, not only future theologians, but all who wished to live wisely and well must study. Emphasis was laid on the duty of the heads of families to provide and supervise a Christian education for their children. Men of means were also exhorted to provide education for the less wealthy by founding schools. Through the study of scripture, man would become morally more upright and a better citizen. Indeed, the humanist emphasis was on the formation of character rather than the acquisition of knowledge. In the view of civic humanism, (humanist ideals directed to the betterment of the state) the end product of a humanist education should not be a better disputant or a bettex philologist, but a better man. Through the production of better men, the ultimate goal of a better state could be realized.

Humanists stressed the education of the nobility. For centuries, available education had gone to members of the 
non-noble classes to train them to be literate assistants to the ruling nobles. By the sixteenth century, many decried the fact that positions of importance in the royal administration were increasingly being granted to men of low birth, because they were more qualified than those of gentle birth. The idea of the nobility of learning began to be quite wellaccepted in intellectual circles, and the evex current subject of birth and learning impelled one Francis seager to write this rhymed paraphrase of Castiglione:

$$
\begin{aligned}
& \text { Experience doth teach and show to thee plain } \\
& \text { That many to honour by learning attain } \\
& \text { That were of birth but simple and base, } \\
& \text { Such is the goodness of God's special grace, } \\
& \text { For he that to honour by virtue doth rise } \\
& \text { Is double happy and counted most wise. }
\end{aligned}
$$

This was capped with exhortations to all estates and conditions of men to fulfill their proper functions in society. 
CHAPTER V

THE MAJOR HUMANISTS: Erasmus

The foremost advocate of humanist learning in England was Desiderius Erasmus. Born in Rotterdam in 1466, he entered St. Lebuin school in Deventer in 1475 where he came into contact with certain masters belonging to the Brethren of the Common Life.* Soon after, his parents being dead, Erasmus was taken from the school and placed in the monastery school of Bois-le-Duc. The contrast between his new surroundings and the freer and more stimulating atmosphere at Deventer undoubtedly had a decided effect on his educational views later in life. In 1487, he entered (how willingly is not known) the Augustinian House at stein near Gouda. In 1488 , he made full profession and was ordained a priest in 1492.28

* The Brotherhood of the Common Life was an association or brotherhood (it was never a monastic order under vows) of devout men who dedicated their lives to industry, teaching and learning. In the period of the close of the Middle Ages, and the beginning of the Renaissance; no schools were more frequented or enjoyed so wide a reputation as those connected with certain houses of the Brethren. It is not to be said that the Brethren enjoyed a special affinity with the humanist spirit in Italy, but they exhibited an absence of distrust in learning and a sympathy with higher aims and methods of education. In only a few cases is it known that the Brethren actually taught in. schools. Chiefly, they received into their houses as boarders pupils attending civic or parish Latin schools, watching over them spiritually and moraliy, and undoubtedly aiding them in their studies. (Woodward, william Harrison, studies in Education During the Age of the Renaissance, 1400-1600, New York, Teachers College Press, Columbia University, 1967, pages 82-3.)

${ }^{28}$ Woodward, op. cit, pages 105-107 
Before taking the first vows, the Augustinians gave Erasmus much leisure time for study and he used it to satisfy his two main interests, classical reading and theology. When he finally took his novice vows, however, his books were taken away, to teach him the lessons of holy obedience. For a scholar like Erasmus, such an existarce was intolerable. The young man was finally pitied by the prior who advised Erasmus that even though monks could not repudiate their vows, they could get special permission from the pope for non-residence. Erasmus threw himself at the mercy of the Bishop of Cambrai. In 1493, he finally escaped the monastery to become the secretary to the Bishop and had the good fortune to be sent by his patron to Paris to be a student of theology. 29

At Paris, Erasmus fell in with a group of English students and at the invitation of one of them, Lord Mountjoy, traveled to England in 1499. It was the word and example of John Colet which first changed Erasmus' desultory ocupation with theological learning into an object of his lifelong pursuit. This new occupation with theological studies set him on the road to becoming the foremost advocate of the new learning. 30

${ }^{29}$ Froud, J. A. ' Iife and Letters of Erasmus, New York:
Charies Scribner's Sons, 1894, pages $17-20$.

${ }^{30}$ Huizinga, Johan, Erasmus and the Age of Reformation, New York: Harper \& Brothers, 1957, p. 33. 
He began his career as a humanist by publishing criticisms on scholasticism, specifically pointing to disputations over points of grammar which never reached a clear conclusion, endless commentaries, each more obscure and further from the original than the last, as well as confusion of divinity and philosophy in scholastic theorlogy. All this he held up to ridicule in Praise of Folly, written ir 1509 .

To Erasmus, antiquity stood for a Golden Age, as humanist scholarship had not yet produced a critical judgment of actual conditions during the great age of Athens or th? Augustinian Empire. The Roman world was seen as an ideal, at one time realized, of a universal state ruling its subjects in peace and justice adorned with arts, letters, and the achievements of practical skill. Mankind had lost all this through barbarism. Renaissance scholars aimed at recovering the ideal. Hence, to Erasmus, antiquity was not a subject of liberal study alone, but the ideal social order which was to be adapted to moderr conditions. This meant especially, adaptation to the supremacy of the christian faith. Progress meant going back to the ancient ideal, once perfectly realized in the past. 31

The problem in transfering the ancient ideal to other countries is that the history, language and culture belonged to Italy. To an Englishman, Latin was a foreign language, and no matter how perfectly learned, the results were never 
quite the same. In Erasmus' writings we find an obstinate refusal to admit the inevitable difference in position of Latin in Italy and the northern countries.

Erasmus used four main points to prove that the acceptance of humanism was the best training for life in the modern world: ${ }^{32}$ 1) The study of classical languages and literature strengthens religion and tends to lead one to more intelligent views of the grounds of faith, and dissociates Christianity as a living force from current superstitions and corruptions. Further, the study of the moral teachings of the finer minds of the ancient world is a support to true religion. 2) Erasmus found in antiquity a politico-social ideal of supreme importance in his own age. Rome was a standing witness to the reign of law and peace with the resultant benefits of the spread of knowledge and the well-being of the helpless part of mankind. 3) OnIy through the systematic study of the ancient writers could human knowledge be purified and advanced, for he believed that within the two literatures of Greece and Rome are contained all the knowledge which we recognize as vital to mankind. There is a great deal of truth in the contention that in most branches of knowledge, especially in applied science, the level of Greek and Roman attainment had not been recovered. Hence, the importance of first-hand acquaintance with ancient books. 4) Erasmus, like the Italians, perceived the intimate relationship between

32 Ibid, pages 112-115. 
humanism and behavior. The ancients had developed a social code and standard of personal bearing to match the worthiness of their ideal of the inner life. Following this, one of the characteristic tasks of Renaissance Italy was to work out the ideal of the modern man in society. Behavior follows interest. Hence, a boy privileged to walk in the company of the great minds of old would quickly be taught how to adjust his outward bearing to society, and how to manifest in his whole personality that inward civility of the mind which is the product of noble studies. On such grounds, Erasmus wrote his manual De Civilitate Morium Puerilium for the profit of the boy, and insisted repeatedly that the duty of both parents was to provide for him a home environment that would cause him to unconsciously regard himself to be of gentle background.

It was evident to Erasmus that this beneficent influence of classical culture could only operate through the education of the young generation. He put his best efforts to the task of stimulating the spread of a truer concept of what education implied. He seemed to have had an intimate knowledge of the problems involved; his insight into the nature of children is remarkable; he perceived the need for reforming the education of. women, and deals in the spirit of sound common sense with the first stages of teaching. Erasmus adopted the best ideas or curriculum current in Italian schools. Though never actually engaged in teaching children, Exasmus was essentially a practical "educator" 
whose advice few schoolmasters in Europe would have dreamed of disregarding.

The Erasmian psychology was like that of most humanists who stood outside the influence of the Reformation. Individual progress in the mental sphere was determined by three conditions: nature, training and practice.

By nature, I mean innate capacity for being trained, partly native, but toward excellence. By training, I mean the skilled application of instruction and guidance. By practice, the free exercise on our own part of that activity which has been implanted by and is furthered by training. Nature without skilled training must be imperfect, and practice without the method which training supplies leads to hopeless confusion. 33

Thus, there is no limit on the effect of wise education, and at the same time, neglect or perverse training may drag down a nature of promising capacity. This is the view of human nature which luther saw as perilously Pelagian, in that it postulated innate goodness, and complete freedom of the will, and was scarcely consistent with the conviction of original sin.

It may be safely assumed that to Erasmus, education meant training for social service in the church, state, city and family; merely professional studies held little appeal to him. The development of individual capacity and erudition through the study of great civilization is the true means to effectiveness in every walk of life. Practical experience was not considered to be an adequate preparation for a practical life.

${ }^{33}$ Simon, op. cit., page 118. 
Education on humanist lines implied an "order of the learned," to use More's phrase. ${ }^{34}$ Utopians made the choice of a few which were to be exempted and discharged of all other labors, and appointed only to learning; that is to say, such in whom,

the people. . have given perpetual freedom from labor. . . so that they may learn thoroughly the various branches of knowledge. But if any of these scholars falsifies the hopes entertained of him, 35 he is reduced to the rank of workingman. 35

This expresses the attitude of humanism to the question of distributive education. The ideal was to educate a privileged minority in no way determined by birth or wealth, but by capability. The tendency was to set up a class, not narrow or professional in type, but an educated upper-middle class, upon whom would fall the responsibilities which were slipping from the feudal aristocracy. Therefore, it is true to say that the Renaissance offered little in the way of educational hope to the masses, but only for the individual who rose out of his class to receive training for a rank above it.

One criticism against the humanist program has been that no contribution was made to the problem of the education of chilaren from birth to seven or eight. At least

34 More, Sir Thomas, Utopia, translated by Ralph Robison, London: MacMillan \& Company Ltd., 1908, page 78.

${ }^{35}$ Sturtz, Edward S. J. and Hexter, J. H., editors, The Complete Works of St. Thomas More, Vol. 4, New Haven and London, Yale Univ. Press, 1965, pages 131-133. 
some, however, recognized the existence of the problem and tried to solve it. Erasmus devoted the most important of his specifically educational writing, De Pueris, to questions relating to the first steps in education. He realized the force of heredity, of unconscious imitation, of early impressions, both aesthetic and moral. He rated the direct function of the mother to be low. Like many other humanists, he knew of the poor training. women received in his day. Erasmus was willing to allow the mother oversight of the child until the age of six or seven, when matters of health, religious impress, exercise and control of appetite become a main concern. Although he attached high significance to bodily fitness in early childhood as the basis of future intellectual vigor, Erasmus had'little or no feeling of the Greek idea of physical perfection which was an essential factor in the concept. of the "complete personality" of the Italian Renaissance. 36

The duty of laying the first foundation of instruction belonged to the home. While systematic instruction was seen as undesirable before the seventh year, at the mother's knee would be learned the elements of the Christian faith, the observance of the Church order and the moral basis of Iife. The child would also receive training in refined speech and elements of reading, writing and drawing. With the seventh year, the boy reached the age of systematic education. While erasmus would prefer home tuition under the father's

${ }^{36}$ Woodward, op. cit., page 118 . 
direction, he realized that few fathers had the leisure and fewer still the necessary capacity. In that event, the choice lies between a civic day-school and a highly qualified praeceptor engaged to teach a small group of boys in the home of one or another of them.

Training in moral duty and religious obedience were the highest ends of all right education; the home alone could lay the foundations of character. Erasmus felt that neglectful parents do "wrong to their country, to which . . they give pestilent citizens. They do equally wrong against God, at whose hand they receive their offspring to bring it up in his service." 37 Individuality should be encouraged; travel was urged as needed for widening horizons and inducing tolerance. The common end was the development of the personality for the due service to the community and to God.

${ }^{37}$ Simon, ㅇ‥cit., page 104 . 
Another prominent humanist figure who influenced English Humanism was the Spaniard Juan Luis Vives (14921540). Although not as distinguished as Erasmus in the width of his outlook over both the ancient and the modern world, of lesser ability as a judge of men and more sparing of literary production, vives was a more thorough scholar, more skilled as a teacher and had a stronger grasp of the educational needs of the age. ${ }^{38}$ He was a pioneer in his field during his age, because he was the first humanist to submit to systematic analysis the psychology of Aristotle and to regard the results of his study in their bearing upon instruction.

After receiving a sound education at home, tinged with at least the rudiments of humanism, he went to Paris in 1509. In the year 1512, he left Paris for Louvain where he became actively engaged in the University. It was at this stage of his career that vives formed his personal friendship with Sir Thomas More. Around 1518, he became tutor to the youthful Cardinal william de Croy, and on his death in 1521, continued to live at Louvain until in 1522 he came to England for the first time, at the invitation of Queen Catherine. In the following year, he was invited by Wolsey, to take the University Readership in Humanity which he had just established, but Catherine persuaded Henry that he 
would be better employed as tutor to Princess Mary and the other girls at court. 39

When the King's divorce became the preoccupation of public men, Vives, quite naturally took the Queen's side in the great controversy; he became suspect, was kept in some kind of modified restraint, and was dismissed and ordered to quit the kingdom. He lost the King's pension and in 1529, the Queen's also.

Vives felt that in an age of rapid social and political change, the progress of knowledge was slow and he wrote a work examining the reasons, De Causis Corruptarum Artium. In the seven books which deal with the subject, vives examines 1) the general causes of the decay of knowledge which to him were avarice, arrogance of the unlearned, unwillingness to stoop to learning, wars, loss of learned tongues, confusion of different regions of knowledge, ignorance of the real Aristotle, corruption of the universities; 2) lack of true instruction in Latin and Greek; 3; the perversion of logic as an instrument of inquiry; 4 ) the want of trained powers of expression; 5) ignorance of sound natural science; 6). the decline of true study in moral philosophy; and 7) the degenerate methods of the study of law. 40

Concerning the care of the young, Vives offered advice which coincided with that of Erasmus. Vives perceived

\footnotetext{
${ }^{39}$ Martienssen, Anthony, Queen Katherine Parr, London: Secker and Warburg, 1973, page 21.

40 woodward, op. cit., page 183.
} 
the law of heredity and allowed full weight to it in the training of the young. Yet, he urged parents to their responsibilities in the child's upbringing, for school cannot eradicate the evil impulses fostered by wicked example or the gross neglect of home discipline. It was the father's duty to oversee everything that concerns his son: he will stiffen domestic control, keep in touch with all that affects the health and occupation of the boy, and above all, select the teacher or tutor into whose charge the boy is placed. The mother may teach the letters, read aloud edifying stories and give the first grounding in morals. Such duties are a stimulus to a sensible woman to continue her own study that she may be a help to her children. Vives believed women to be lacking in strength of will, and as the source of much of the lack of self-discipline shown by young men on entering manhood. Further, Vives would allow a mothar to flog her son, while Erasmus regarded that as dishonoring to both.

Iike Erasmus, Vives advised that a boy in his seventh year be sent to the "gymnasium civitalis publicum" with opportunities of attending courses in Arts at a university, where one is available. The student should board with a relative or friend competent to supervise. He objected to boarding schools, feeling that schoolkeeping had become such a profitable undertaking that much money was made out of the boarders. As a layman, Vives seemed always to prefer a lay institution to a monastic or clerical school, and 
believed that in every city and in certain county centers there should be a public school.

Vives differs fundamentally from Erasmus and Sturm in respect to the function and worth of vernacular tongues. Vives was been brought up, as were all spanish humanists, to be proud of his Castelian, and he wrote, "It is the duty of the parent and of the master to take pains that children speak their mother tongue correctly." 41 The master must be competent in the vernacular of his pupils or he will fail to teach adequately the classical tongues using the vernacular. Further, a rightly educated man will do his utmost to foster and enrich his national speech.

Ideally, Vives felt that the perfect state implies one race, one nation and one speech. However, the realities of life are against the attempt to assume such conditions, hence the further need for a universal language. Interaction between foreign peoples, the common faith and literary works of permanent and universal interest demand such a language. By its history, structure and relation to its romance offshoots, Latin is clearly the choice for a Universal language.

According to Vives, boys should learn Latin between - ages seven and fifteen when they are not yet ready to understand other branches of knowledge. After acquiring the first element of grammar, the student should be given a Latin text. In addition, Vives advised the use of a

41 Woodward, op. cit, page 197. 
special notebook for each student, with divisions for vocabulary, history notes, anecdotes, weighty judgments, witty or acute sayings, names of famous men or towns, and so on. It was very important to vives to involve the student in education, making him practice instead of merely listening and memorizing.

Concerning the ancient authors, Vives would not admit that antiquity had produced a type of mind of a different order from that which the modern world could show, and he ridiculed the excessive veneration of Cicero. Antiquity presents subsequent ages with examples of men passionately devoted to truth and laborious in pursuing it. In reverencing their spirits, however, it was not necessary to affirm that they had attained final truths in all subjects. The classics were to be studied with the view of eventually surpassing them, if possible.

In keeping with the humanist reverence for history, Vives felt that students should be given a general outline of history to the present, preceded or accompanied by a course in geography. He goes on to ask what elements of history are of chief importance. Not wars, he says, for these are largely mere brigandage and should be treated as such. As facts, they are to be noted but merit no special study. A pupil should deal chiefly with civil history, with events and characters worthy of commendation, leaving political lessons for a more advanced stage, when a youmg man might 
take up the study of such as a technical preparation for public service. Such an attitude toward the past relieves Vives of any anxiety of the moral dangers of the study of ancient Iiterature and society. He is able to take the historical standpoint and permit the use of antique wisdom along with the Christian fathers and scripture.

Among his many qualifications, Vives made a special study of the education of girls and young women, believing not so much in the equality of women, but in the need for them to acquire the type of wisdom which would enable them to overcome the weaknesses of their sex. ${ }^{42}$ His objective was for women to be instructed in that part of philosophy "which taketh upon it to inform and teach and amend the condition of living." He was very concerned that women should learn to understand men, whether as husbands, lovers or simply in everyday dealings, so that they would not be duped by men, in the case of wives so they would have happier marriages, and so that women could learn to control men without being too obvious about it. 43

The medieval judgment upon the education of women which survived in German, French and English societies down to the Reformation was a natural outcome of the subordination of women in feudal communities. The influence of territorial and still more of ecclesiastical authority was

42 Martienssen, op. cit., page 22. 
against all pleas for the enlargement of the scope of women's lives. The training for domestic duties, which were hers by nature, covered reading, writing, "computatio," with rudiments of medical and surgical lore so as to qualify her to nurse in the event of sickness or injury. Other necessary accomplishments were needlework, spinning, music, astrology, and, less commonly, French. Religion was, ostensibly at least, a subject of prime importance.

The pre-Reformation view of women was that of a temptress, and for a man, the celibate life of a monk was the best. Luther and Calvin, through their writings, helped to emancipate marriage from negative overtones. ${ }^{44}$ other reformers did much to achieve improvement in the status of women; the patriarchal system persisted, but it was seen more generally to be the man's duty to educate his wife and children. As is obvious even in this day, old ideas die hara.

Though certainly the most sought after, the court was not the only center of women's education. Daughters would be sent to houses of other families, much as were sons, to train under the supervision of the lady of the household and a private tutor. There they would receive an education which would fit them for their vocation of marriage and running their own households.

${ }^{44}$ Charlton, Kenneth, Education in Renaissance England, London: Routledge and Kegan Paul, Lid., 1965, page 204. 
Views on the education of women in Italy were strikingly different than in northern Europe. Leonardo Bruni was the first to advocate that the treasures of ancient literature not only be thrown open to women, but should form an integral part of her education. Vittorino was perhaps the first schoolmaster to carry into practice the doctrine of the equality of the sexes. In Italy, the social status of women underwent a great change during the quattrocento. The new place which she came to occupy in society necessitated wholly different training and much wider and more thorough instruction than was permitted her sisters in northern Europe. It was not that women, in virtue of their education forced their claims to a new social recognition, but the freer, worthier status of women compelled a higher type of training to correspond to it, an accordance with the universal law of educational advance. Thus, the new frame and content of education touched only those women who belonged to the class in which their social equality with men was accepted. This was never a large class.

In England, there were schools for girls, but the inteligence of women was not taken seriously, except by an enlightened few. Erasmus regarded women as weak, frivolous, unstable and irritable, though he recognized that their education and usual interests were unfavorable to moral and intellectual force. It was precisely on the same grounds that vives thought it essential in the interests of the 
community that the problem of the training of girls be attacked.

A women, he urges, needs "to be fortified by the aid of wise philosophy" for she is weak. Moral dignity is the glory of the woman, and ignorance is no safeguard against vice. True learning affords both example and stimulus for a finer moral purpose. Vives felt that many women are difficult, morose, fond of dress, absorbed in trifles, arrogant in success, abject in misfortune because of lack of sound interests such as learning will afford. Never, he affirmed, has he known a well-educated woman to fail to command respect. Many subjects suitable for men are omitted for women, including natural philosophy, mathematics, history (except for illustrations of good and evil) and rhetoric, since woman's duty is mainly to keep silence. 45 vernacular speech, taught with great care, held the leading place in the curriculum for women. Then followed latin and poetry with careful supervision. Vives would allow no modern romances but recommended instead books on child-rearing, household management and nature study to promote skill in nursing .

The general end of a girl's training was the preparation of a devout, high-principled lady, affectionate wife and mother, the equable, intelligent companion and, above all, the skilled mistress of the house, with serious

${ }^{45}$ Woodward, op. cit., page 208 . 
interests on the leisure side of life. This approach was not unlike that ideal worked out by Thomas More for his own daughters. 
CHAPTER VII

THE MAJOR HUMANISTS: MOre

Thomas More was a most important humanist figure in many regards. Not only was he one of Erasmus' closest friends and an advisor to the king, but he fashioned his household on humanist lines, insisting on a completely humanist education for both of his wives, his daughters and son; adopted children and'even for his servants. More was born in 1477 or 1478 , the son on a London lawyer. He attended st. Anthony's school, considered to be among the best in London, for five or six years, and then joined the household of Archbishop John Morton at Lambeth Palace. At the age of fourteen, he was sent to oxford, possible Canterbury College.' After two years at oxford, More entered the New In (probably 1494) to begin his law training preparatory to entering Lincoln's Inn in 1496. He completed his law studies in 1502 .

More's interests ranged far beyond'his legal training. He became proficient in Greek and pursued other non-legal subjects to the point that his father, according to Erasmus, " . . decided to check these studies by cutting down his son's allowance; in fact, More was all but disowned for apparently deserting his father's profession. "At?

16 Reynolds, E. E., Thomas More and Erasmus, New York: Fordham University press, 1965, page 135. 
For three or four years, More lived in the Charterhouse of London, sharing the devotional life of the monks without ever taking the vow. By 1505, he was married. It is not known what made More give up the contemplative life, but Erasmus, More's most intimate friend and a priest himself, wrote:

At the same time, with all his powers he turned toward the religious life by fasting, prayer and similar tests, preparing himself for the priesthood; more wisely than many who rush blindly into that arduous calling without first making trial of themselves. And he had almost embraced this ministry, but, as he found he could not overcome his desire for a wife, he decided to be a faithful husband rather than an unfaithful priest. 47

Thomas More took very seriously his role as a husband and father, and fashioned his home to provide the most ideal humanist education possible. More's inclination was towards the monastic life and his alternative to the contemplative life was to devote his whole purpose to his children and his home. He wrote to his daughter on one occasion,

I beg you, Margaret, tell me about the progress you are making in your studies. For I assure you that, rather than. allow my children to be idle and slothful, I would make a sacrifice of my wealth, and bid adieu to other cares and business to attend to my children and my family, among whom none is more dear to me than yourself, my beloved. daughter. 48

More's household was basically that which he wrote about in Utopia. In both of his worlds, the ages were carefully mixed so that the young and old could learn from

47

Ibid, page 33.

48 Basset, Bernard, S. J., Born for Friendship - The Spirit of Sir Thomas More, Ner York: sheed and Ward, 1965. 
one another. The Mores were a clan, not a family, as More welcomed as equals any number of guests. The More household was forever increasing in size until he was taken to the Tower. The long line of tutors were regarded as part of the family as were the spouses and children of his children. From their tenderest years, the children had to study. They did not study to make their names, to make money, to make an impact on the world about them, but simply because study was a reward and pleasure in itself. For More, intellectual development according to the capacity of the individual meant self-completion, self-expression and lasting happiness. To him, study was a God-given talent and led man to God. The children applied themselves to Latin every day, translating from Latin into English and then, later, turning their English version back to Latin again. No distinction was made between the boys and the girls. More, who was a pioneer in the education of women admitted that girls might have certain initial problems, but he treated each child individually. As he wrote to Gonnell in. speaking of the training of his daughters and his son,

Nor do I think that the harvest will be affected whether it is a man or a woman who sows the field. They both have the same human nature, and the power of reasoning differentiates them from the beasts; both, therefore, are equally suited for those studies by which reason is cuitivated, and is productive like a ploughed field on which the seed of good lessons has been sown. 49

His method was rewarded, for both Meg and his adopted daughter

49 Reynolds, op. cit., page 135 . 
Margaret Giggs became accomplished scholars, two of the best educated women of their day.

One reason why the children did not find their studies dull lies in More's own approach to learning and the care that he took to encourage the adults to study as well. More saw learning as a pleasure, never a chore. As the scholars of his school grew up, they continued their studies, often competing with More and their tutors in intellectual exercises. Greek, Latin, Astronomy, Music, Declamations were but a surface view of More's educational plan for his children. For More, study was a spiritual weapon, essential both for human happiness in this world, and for spiritual progress towards the next. Study began with the scriptures, but More did not confine his attention to spiritual study, as he thought that all genuine study led to God. In the education of his children, More's motives were typical of his whole approach to life. He wanted his children to study and grow wise, "because the reward of wisdom is too solid to be lost like riches or to decay like beauty, since it depends on the consciousness of what is right, not on the talk of men than which nothing is more foolish or mischievous." 50 More's fictionalized ideal in Utopia and his actual home were strikingly similar. In Utopia, there are no classes, if by class is meant hereditary privileges or disabilities which separate one from another. Everybody is born free and given the same opportunities. The same

50 Ibia, page 128 
education is provided for all, women as well as men, and all are expected to do the same amount of work. No idleness is tolerated and as all Utopians perform manual labor, the hours of work could be restricted to six per day or fewer. There are in Utopia, three kinds of students. The first are scholars by profession. Only 500 out of an adult population of between 60,000 and 100,000 are excused from manual labor and only 300 of the 500 are allowed to devote themselves exclusively to learned studies. They are highly respected and out of this group the higher magistrates are elected.

The second group consists of children of school age, because literary education is universal and compulsory in Utopia. It is here that More makes a distinction between education and learning, though the distinction is not intended to be a strict one. Education applies to discipline and training, often unconscious, received at home, in church, in public, at play and at work, almost independently of all but the most elementary schooling. Learning embraces knowledge gathered at lectures or from books. 51

The third group constitutes a good part of the whole population, both male and female, who throughout their lives devote to literature the many hours they have free from manual labor. Lectures are provided for those selected

${ }^{51}$ Surtz, Edward, S. J., The Praise of Pleasure - Philosophy Education and Communism in More's Utopia, Cambridge: Harvard University Press, 1957, page 78. 
for learning, but many others take advantage of the opportunity to improve their minds. Great crowds voluntarily attend the morning lectures along with those who are required to attend. This passion for knowledge was shared by the Utopians and those in More's household, and is in complete agreement with More's philosophy of pleasure. Literature becomes the object of love because it is the source of great pleasure.

More sets out in Utopia a humanist program for reform of studies which expresses it self as a plea for careful scrutiny of the Greek classics. The Utopians are philosophers and study the quadrivium: arithmetic, geometry, astronomy and music. In the Republic, Plato assigned the reasons for studying those subjects and they are More's reasons as well. Arithmetic is intended "for the uses of war and for facilitating the conversion of the soul itself from the world of generation to essence and truth." Geometry is suitable for the conduct of war. Astronomy is "serviceable, not only to agriculture and navigation, but still more to the military art." Finally, music is important in education "because more than anything else rhythm and harmony find their way to the inmost soul and take strongest hold upon it, bringing with them and imparting grace, if one is rightly trained." 52 The ideal which More set out in Utopia was that which he wished to accomplish in his own household. His attempt

52 More, op. cit., pages $184,187$. 
was successful, not only during the thirty years which he held his household together, but even after, as his children attempted to set up their own households and to train their children in his ideals. More's humanist school was an ideal which could be attained by few others in England, as few had the financial resources which were necessary to support a household of some forty children, friends, tutors and servants. Even more, few men had the beliefs of More which caused him to regard learning as not only the right of all, but the duty of all.

Many humanists of More's day and after sought to establish humanist schools for the public's children. These plans met with varying degrees of success and will be examined in the next chapter. 
CHAPTER VIII

THE MINOR HUMANISTS

Humanist ideas became very popular in English intellectual circles during the first half of the sixteenth century. Many men of lesser renown, with the great aid of the printing press, were making their ideas available to the general public. Among those whose works and ideas became well known to the public were Thomas Elyot, Roger Ascham and Richard Mulcaster.

A. Thomas Elyot - Thomas Elyot's The Boke Named the Governour, addressing the upbringing of the young noble, was a type of writing which became especially popular during this time. 53 published in 1531, the object of the Governour was to instruct men in such virtues as shall be expedient for them. It was not a political treatise and makes no attempt to set out methods of government. Nor was it the sketch of a perfect state, for Elyot always had England and Englishmen in his mind with an undoubtedly forward look. Elyot realized the need for a sounder concept of training for the sons of the governing class. The ideal of service to the state, lay and civil, was a new one in England and Elyot saw that it would claim its place beside the older

\footnotetext{
${ }^{53}$ Examples of such works are The Courtier, by Baldassare
} Castiglione, Advice for a Son and Institution of a Gentleman, both by anomyous authors, and induvidual letters such as those contained in Life and Letters in Tudor and Stuart England, edited by Iouis B. Wright. 
ideals of service through arms or clerkship, and ul.timately would surpass them in importance as the ecclesiastical and feudal territorial privileges yielded to the authority of the King's court.

Widely read in classical and the neo-Latin literature of Italy, Elyot realized the need of liberal training for all who aspired to share in the administration of affairs. He expressly disclaimed the idea of debarring men of humble origin from high office, but his scheme of training demanded a certain standard of wealth and refinement in the home, and parents capable of taking broad views.

In the course of education, Elyot began with infancy. The nurse must be carefully chosen with her moral and physical fitness duly assured; her one function was nourishing the child. No men except the physician are to be allowed in the nursery. In later years, the father should take an active part in the education of his children, assuring especially that all who come in contact with the noble son speak eloquent and pure Latin, or at least perfect English. Elyot stressed three of the most important points in the training of children which were stressed by Erasmus: 1) the necessity of careful attention to the habit of clear and refined speech in childhood; 2) the principle of instruction by methods of play in the first stages of teaching; and 3 ) the value of the conversational method of learning an unknown language, in this case, Latin. 54 
In keeping with the common opinion of humanist writers, Elyot states that "After that a child is come to seven years of age, I hold it expedient that he be taken from the company of women:" This is based on his basic distrust of the companionship of serving women, and even the mother, seeing that the sterner side of character needed to be encouraged in the growing boy. The best approach was to remove him entirely from the company of women and assign him a tutor who should be an ancient and worshipful man, winning the boy by his gravity of temper combined with gentleness. He should be such a man that by his imitation the child may grow to be excellent. The essential quality of a tutor is moral excellence, and if he be learned, so much the better. Elyot adopts the Erasmian and northern idea of the necessity of a tutor to a well-born boy. The contrast to the Italian practice of school or joint instruction is due to the difference in social custom between the two countries. In England and Germany, the upper class was essentially a country class; in Italy men of wealth and status craved the society and comforts offered by a city. The English passion for outdoor pastimes and the quasifeudal status of landowners made the country life the one acceptable alternative to training at court. Later on in the century, Roger Ascham could regard English education from the point of view of the school. By that time, the Elizabethian court had popularized the "town" as the center of society, and traveling in England was such an easier matter that the great boarding and day- 
schools, such as Eton and Westminster drew the youth of family. 55

According to Elyot, the test of a tutor's skill was

that he suffer not the child to be fatigate with continual study or learning, wherewith the delicate and tender wit may be dulled or oppressed; but that there may be therewith interlaced and mixed some pleasant learning and exercise, as playing on instruments of music, which, moderately used, and without diminution of honour, that is to say, without wanton countenance ang dissolute gesture, is not to be condemned.

Elyot realized better than Erasmus the effort involved in a hard literary and linguistic course for a boy, and the difficulty of retaining prolonged interest in the exclusive study of the rudiments of ancient languages. From this point of view, he included music as a recreation and not as a systematic study. The use of music for the "refreshing of wit" was commendable, but the tutor was directed to rebuke excessive devotion to it.

Concerning other methods of recreation for the gentleman, Elyot had much to say. The general end of exercise was bodily health and fitness for study and as such, exercises were carefully prescribed. Wrestling, then a typical English sport, headed the Iist, followed by running, which is defended by Epaminondas or Achilles, swimming, which could be useful in certain dangers, and hunting red deer, fox or hare.

\footnotetext{
${ }^{55}$ Woodward, op. cit., page 276 .
}

56 Ibid, page 277 . 
Hawking is not one of the nobler sports, but is good for one's appetite. Riding was a necessary accomplishment; the long bow was seen as the most commendable of all sports of its utility in national defense, and as a pastime and solace.

Elyot's view of historical writings as a concise record of military, political and moral wisdom was a more intelligent view of history than was obvious even in the best schools of the Renaissance, where history was mainly confined to edifying biographies. Yet, no reference is made to Medieval or modern history as a subject of study, because Elyot did not believe in the ability of contemporary vernacular authors to write history or to present moral conclusions. The student sufficiently trained in the finished literary histories could afterwards, as need arose, consult the chronicles and analysts of his own or other countries for such advantages as could be gained from them.

Elyot propounded the fundamental principle of humanist education, illustrating it from his own experience:

I think verily if children were brought up as I have written, and continually were retained in the right study of very philosophy until they passed the age of twenty-one years and then set to the laws of the realm . . . undoubtedly they should become men of so excellent wisdom that throughout all the world should be ${ }_{5}$ found in no commonweal more noble counsellors.

He lamented the habit of putting promising youth prematurely to study Iaw, to court service or to the life of the manor 
house. He found that the education of children from ages fourteen to twenty-one is mostly ignored, and a small ability for reading latin is seen as adequate proof of fitness for a career, whereas it is but a base for the actual edifice of learning. A youth of fourteen put to law likely finds it intolerable, and throws it up with all intellectual interest whatever.

To Elyot, true nobility is constituted of personal merit, yet inherited repute, title, lands and position are accounted nobility also, and when the two are united, there is conspicuous distinction. However, the common attitude toward a gentleman's life and toward letters in the first half of the sixteenth century was not entirely favorable to meritorious living and learning. As expressed by the anonymous author of Institution of a Gentleman (1555),

What is a man if he knows not how to wear his apparel after the best fashion, to keep company with gentlemen, to stake his twenty nobles at cards or dice? If he be unwilling to do that, his is a lout or a miser, one who knows no fashion. But it becometh a gentleman, they say, to be a roysterer, which word I do not well understand, unless it signify a ruffean. If a young gentleman use many vain words then they say that he can talk well and hath a good wit, but, if he talk wisely indeed, they say, 'the young fox preacheth.' If he understands somewhat more in learning than they do or get his living by way of writing, then in despite they call him a penman.

Elyot concludes that what hinders the modern world most from attaining the virtues and learning of the ancients is the pride, avarice and neglect of parents, and the lack of good masters. 


\section{B. Roger Ascham - Roger Ascham (1515-1568) has two}

claims to fame as a humanist. Not only did he write a book setting down ideals of humanistic education of young nobles, but he was for a time tutor to Elizabeth. Writing in English to reach the widest possible audience, there is Iittle startling or new in Ascham's The Scholemaster, but the work stirred the minds of many Tudor readers whose own memories of rearing by over-indulgent parents and harsh, unimaginative schoolmasters had often been unhappy.

In 1548, Ascham became tutor to the Princess Elizabeth. He found her more intelligent and industrious than any pupil he had known in the university, and tried to educate her according to the best ideals of contemporary religious humanism. This ideal meant developing her mind and character by combining the best the classics had to offer with the saving dogma of religious faith. Ascham aimed to fashion Elizabeth into a learned and pious adult, suitably prepared to fulfill whatever role was destined to be hers in a Christian commonwealth. He was able to see the results of his teaching methods when he became Latin secretary to the young Queen in 1558. The methods which Ascham tried out on Elizabeth were later to form the basis of his book The Scholemaster. In this work, Elizabeth is set forth as the pattern after which all well-born youth ought to be fashioned. 
Ascham spent many years teaching at Cambridge before going to court in 1548. Thus, his warnings about the dangers of court life stem from his own experience. While tutor to the Princess Elizabeth, Ascham lived in the midst of the great scandals which surrounded the young girl. He was well aware when writing his book how many temptations lay in wait for those who dwelt in the royal households and how precarious was the courtier's position.

In his views on pedagogy and the psychology of learning, and even in his observations on literary craftsmanship, Ascham occupies an influential and honorable position in the evolving tradition of Renaissance educational theory and practice. The central aim of humanist educators was to prepare youth for honorable service in society. Having in mind the destiny of most of their pupils to rule or advise rulers, the humanists fashioned their curriculum and moral discipline accordingly. Because of the end they wished to achieve, and because most wrote on the earlier rather than the more advanced stages of education, there is little or no concern shown for speculative knowledge for its own sake, or with fitting youth for specialized professions. Learning was becoming fashionable in Renaissance courts, but not the technical learning of the theologian, physician or lawyer. Courtiers were becoming aware of a knowledge that could make them nobler in character and more cultured in manners, and hence abler and more attractive as counselors to their princes. Princes, too, were being continually reminded that 
learning and excellent character were necessary for those who rule.

The liberal arts given the most attention were those which seemed the most likely to inculcate ethical and political virtues. The subjects most often discussed and extolled in humanist writings are grammar, rhetoric, poetry (i.e. Iiterature), history and moral philosophy. Grammar was indispensable because the noblest thoughts of mankind, both pagan and Christian, were written in Latin and Greek. Rhetoric, or the art of public speaking came next because it was believed that no one wanting in this talent could exert his proper influence in public affairs. History was studied for the actual, and poetry for the fictional or idealized examples they provided of ethical and moral conduct to be emulated or avoided. Moral philosophy was important because a wise man or woman must know the principles as well as examples of good in order to choose the right path and exemplify the finest ideals of human character and behavior. The inspiration for this educational program was, of course, classical. Ancient authors, too, were concerned with how to fit a man to a worthily active life in the state whether as a prince, senator or citizen. Most looked not only for wisdom anā goodness, but also for eloquence in their ideally virtuous man. To the ideals found in classical sources, Renaissance humanists almost always added Christianity. The religious stress in Ascham is accompanied by an exceptionally noticeable flavor of nationalism. While English 
fns in general look toward the prospering of the commonwealth, with Ascham the commonwealth is very specifically a Protestant England, so that in serving the state the properly fashioned gentleman was expected to serve the religion of England as well. 59

Ascham's book, The Scholemaster, was published by his widow two years after his death. While it offers nothing universal in educational theory and was not even the earliest exposition of most of the ideas it contained, it became the most influential of Tudor treatises on education, along with The Governour, to which it was indebted. Through his writing, Ascham provides illustrations on Elizabethan attitudes toward education: the care to be exercised by parents in rearing their children; adjusting the pedagogical system to the individual child rather than the child to the system; teaching by cogent and practical example rather than rote memorization; the preferability of learning to raw, untutored experience and the dangerous allurements that lie in wait for the unwary youthful traveler, especially in Italy.60

Ascham's treatise grew out of a dinnertime discussion with other members of court on 10 December 1563. The men present discussed the merits of beating scholars, prompted

\footnotetext{
59 Ascham, Roger, The Scholemaster, edited by Lawrence V. Ryan, Ithaca, NY: CornelI University Press, 1967, page xxvii.
}

60 Ryan, Lawrence $V .$, Roger Ascham, Stanford University Press, 1963, page 251. 
by a recent episode at a nearby school. After the discussion, one of the gentlemen present asked Ascham for a recommendation of a tutor for his son. He also asked Ascham to write out his thoughts on the education of children; the thoughts which Ascham began to express grew into The Scholemaster. Book one begins with a brief exposition of a few guiding principles for the earliest stages of grammatical instruction. Ascham believed that a child should not be set immediately to translating English sentences into Latin, nor should he be encouraged to speak latin too soon, for that gives rise to faults that may never afterward be eradicated. The pupil should learn by double translation (translating Latin to English, then back to Latin after a few hours time) using the example of Elizabeth to demonstrate the effectiveness of the method. Ascham continues that a master should criticize a child's effort gently, not chiding or punishing him for errors if he has done his best, but commending him whenever he has done well, "For I assure you, there is no such whetstone to sharpen a good wit, and encourage a will to learning, as is praise." 61 Through the loving mastery of Latin, the apt child will come to delight both in good learning and moral discipline, by virtue of reading ancient authors, scripture and the church fathers. However, if he is made to hate Latin by dull instruction and harsh punishments, he may in years to come abandon study

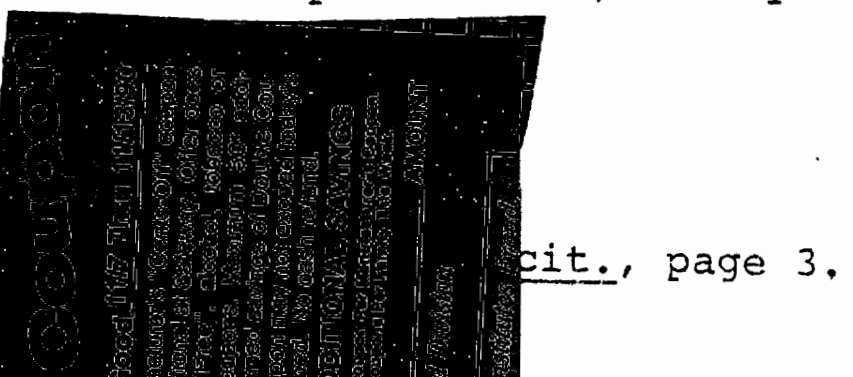


Ascham states that too many Englishmen tend to mishandle the education of their children right from the cradle. Too many masters favor the quick-witted prodigy as against the slower learner, and he gives illustrations of how quick wits are flighty and soon lose their goodness. Dull wits, if handled properly prove best in the long run. It is lamentable, he feels, that parents exert greater care in choosing a trainer for their horses than tutors for their sons and daughters. Thus, in order to help others distinguish real from false intellectual promise, Ascham presents seven "true notes" adapted from Plato's dialogues by which one might detect a "good wit." 1) Euphuis - well endowed with all good qualities of mind and body that serve learning; 2) mnemon - retentiveness; 3) philomathes - predisposed to love learning; 4) philoponos - willing to work and take pains; 5) philekoos - glad to learn from others; 6) zetetikos diligent to investigate every aspect of a subject until he is perfectly taught; 7) philepainos - eager to be praised for doing well. All these qualities, granted that some may be gifts of nature, may be fostered by proper handling and marred by mistreatment of the child.

There is one crucial sentence which epitomizes the entire Christian humanist doctrine of the treatise: if to the goodness of nature be joined the wisdom of the teacher, in leading young wits into a right and plain way of learning; surely children, kept up in God's fear, and governed by his 
grace, may most easily be brought well to serve God and their country, both by virtue and wisdom. ${ }^{62}$ How to keep the young in God's fear so that they may serve him and the commonwealth is the concern of the remainder of Book One; Ascham devotes more space to this topic than he does to intelligence and learning.

Concerning foreign travel, which became increasingly popular as a way to finish off a young man's education, Ascham feels that the morally hazardous voyage to Italy should be avoided above all. Since he had always longed to see the wonders of Italy, and never stopped praising the beauty of the Italian language, the reason for his vehement attack is not entirely clear. Yet it must be remembered that the Marian years led many to identify Italy with papistry and persecution. In addition, some of Ascham's friends visited Italy, and it is likely that their misconduct was more than his priggish nature could take. His was the deep mistrust of the effects of ill-chaperoned travels to Italy which lingers among Anglo-saxon people to the present day. Foreign travel, however, became such a trend by the eighteenth century that particular routes became fashionable, and inhabitants en route organized their economy to minister to the needs of the visitors.

At the early stages, the object of foreign travel was to gain practical experience of other countries, of foreign

${ }^{62}$ Ascham, op. cit., page 32 . 
people, of other languages and the terrain and resources of these countries, all of which would be useful in a future diplomatic or political career. At least this was the aim enjoined upon prospective travelers and their tutors by many books and printed "Letters of Advice" that were being written from the second half of the sixteenth century onwards. The young nobleman's journey was to be regarded as a reconnaissance, with certain well-conceived and practical ends. Not merely topographical or tactical matters were to be noted, but in typically Renaissance fashion, the psychology of the different peoples visited was to be observed:

What is the chief force or virtue of the Spaniards? And what of the Frenchman? What is the greatest vice in both nations? Wherein doth the one or the other most regard themselves or takes greatest delight? In what thing the nobility of France doth differ from the nobility of Spain? . . . and what manner the subjects in both countries show their obedience to their prince or oppose themselves against him? 63

Notice should be taken of buildings, not for historical or architectural value but as a measure of prosperity. Most important, the traveller should mark the government, how it works, who is involved. All this information should be put in a daily journal to be sent home or presented on the student's return.

The English saw great dangers in papist Italy. It was said in 1574 that young men bring out of Italy three things:

${ }^{63}$ Charlton, op. cit., page 216 . 
a naughty conscience, an empty purse, and a weak stomach. James I finally forbade all those going through Venice to go farther than Florence, lest they go to Rome and fall into the company of priests and Jesuits, or were lured away from good by the great moral temptations which lurked there. Yet, not all young men were ruined by a journey to Italy, and the Grand Tour of the student with his tutor continued to be an alternative and, at times, a supplement to traditional forms of education until the advent of the great private schools.

Ascham's educational program was fundamentally that of the ancients adopted to current conditions by the humanists of the fifteenth and sixteenth centuries. Ascham acknowledges his role as a transmitter and his almost total dependence on the prior wisdom of others, borrowing heavily from Sturmius, Checke, Plato, Aristotle and Cicero. Plato, besides providing the key notes of a "good wit" provides such ideas as that the proper rearing of children is the highest trust committed to society; that education begins not in school but in the nursery; that learning ought always to be pleasant business, but the merely pleasurable should be mistrusted because it is often enticement to evil conduct, and that too much moral freedom and license to travel may corrupt impressionable youth.

C. Richard Mulcaster - One humanist writer, Richard Mulcaster (1531-1611) addressed specifically the problems 
relating to the profession of teaching. Mulcaster was headmaster of the Merchant Taylor's School from 1561 to 1586, and of St. Paul's school from 1596 to 1608. He enjoyed his duties and had little patience with schoolmasters who constantly complained. He knew that there existed certain unpleasant conditions in the teaching field, but felt that many could be eliminated by employing better teaching methods. To avoid some of the unfavorable conditions and to achieve a more effective learning situation, teachers should, in his view, adhere to the following: uniformity in teaching, utilization of the best authors, consistency in the rate of presenting materials and judicious use of discipline. Mulcaster also favored a special tax exemption for teachers. Uniformity of teaching was of great importance to Mulcaster. He felt that there was too much experimentation in teaching and thus too many opportunities for unsatisfactory teaching. Mulcaster would have preferred that teaching methods be sufficiently uniform so that every youth in the nation would appear. to have been taught by the same teacher and would be exposed to a common core of learning. Even if the child changed schools, the procedures of one school would conform to those in any other.

Concerning punishment of students, Mulcaster believed that the punishment should fit the crime. Further, he felt that parents should not take offense when teachers punished their children, for it must be assumed that the school 
officials had good reason for taking disciplinary action. He considered it unwise of a teacher to punish a child who was willing to learn but lacked intelligence. Only if a child did not learn because of his own negligence should he be punished. "The ende of our schooles is learning: if it faile by negligence, punish negligence: if by other voluntarie default, punish the default." 64

Mulcaster developed an idea expounded by Vives of holding teacher conferences in which teachers discussed the progress of their students. In the view of Mulcaster, further benefit would be obtained by. holding conferences between teachers and neighbors, 65 teachers and parents, parents and neighbors and teachers of the same child. For complete and unbiased reports, undistorted by parental affection, neighbors could be invaluable in supplying information needed for evaluating the child.

Mulcaster advocated the use of the best teachers in elementary school, for it was there that the groundwork for

${ }^{64}$ DeMolen, Richard L., "Richard Mulcaster and the Profession of Teaching in Sixteenth Century England," Journal of the History of Ideas, January 1974, pages $121-129$.

65 Mulcaster defines neighbors as ". . . all foreign persons, whom either commendable duty by country law or honest care of common courtesy doth give charge unto, to help the bettering of children and to free them from evil." (Mulcaster, Richard, Positions, abridged and edited by Richard L. DeMolen, New York: Teachers College Press, 1971.) 
their future education was laid. Yet since the best teachers would not often teach in the elementary grades because of the low salary, poor living conditions, the lack of respect and the hard work involved in teaching, typically only the poorly prepared teachers were employed. In order to secure the best teachers for the lower grades, Mulcaster suggested that the following conditions prevail in schools: 1) the highest salary should be paid to teachers of the lowest class, because his work was the hardest; 2) the least number of children should be placed in the first form since they were more dependent on the teacher for their knowledge than any of the other school groups. As children advanced in knowledge, the number of students in class should be increased, and the salary of the teacher decreased, because the children learn more readily and the work was not as strenuous; 3) the salary of the teacher should be more than sufficient for his needs since he was rendering a great service to the state, community and parents.

Displaying a special interest in elementary school teachers, Mulcaster also felt that due consideration be given to the grammar-schoolmaster for he was in charge of boys during adolescence and was entrusted with two responsibilities. The grammar-schoolmaster must complete the course of study begun in elementary school, and must prepare his charges for the university. He insisted on employing only scholarly persons as teachers in grammar school so that 
the languages and other disciplines would be properly taught.

Since salaries were low and qualifications minimal, teaching school in Mulcaster's day was simply a means whereby men supported themselves until they were able to enter the learned professions of law, theology and medicine. As a result, the quality of education in the schools varied considerably. To get the most out of a public school, financially able parents were encouraged to hire a tutor and send him to school along with the child so that the schoolmaster would be inspired to the highest standards and the tutor would have something on which to base his private teaching.

Though certainly a radical idea for his time, Mulcaster advocated a teacher's college within the university. He proposed to divide teachers into three classes - the Elementarie, or those who taught the rudiments, the Grammatical, or the teachers of language, and the Academicall, or the university teachers. He recognized the difficulty in convincing the public of his ideas, for were not all university graduates qualified teachers? Mulcaster thought otherwise. One is not necessarily capable of teaching simply because he possessed worthwhile knowledge. It would be the function of the teacher training college to prepare individuals properly for the dissemination of knowledge.

For over twenty years, Mulcaster gained practical experience as the head of one of London's prominent grammar 
schools, and this experience gives his ideas a sense of realism. What is truly unique about Mulcaster is that he provided a system of education that was applicable to all members of English society. Wishing to destroy class selectivity through reform, he was convinced that the artisan could benefit as much from a public elementary education, including music, drawing and the study of the vernacular, as could a nobleman.

Over and over, Mulcaster asserted that children ought to be educated not only in order to fulfill personal needs, or for reasons of character and morality, but also for the benefit of the state. And because the welfare of England depended ultimately on assigning every Englishman to a needed, if not satisfying social responsibility, the individual must be prepared to subordinate his choice of vocation to the well-being of the commonwealth. 


\section{THE HUMANIST SCHOOLS IN THEORY AND PRACTICE}

Humanist theories of education largely remained theories throughout the sixteenth century. Notable exceptions are tutors such as Ascham, whose Scolemaster is based on experimenting with his theories during his career as a tutor. John Colet (1467-1519) was another humanist who sought to put educational theory into practice.

After receiving an oxford education (probably Magdalen College) Colet, in 1493, took a Continental tour. While no details of the journey are known, it is known that he mastered, while in foreign universities, the works of the church fathers and many of the medieval schoolmen, who were stili in vogue in English universities. 66 He also studied canon and civil law, all the books on English history and literature which came his way, and probably made his first acquaintance with Greek.

Colet was ordained a priest in 1497 . He took up residence at oxford and there delivered a remarkable course of public lecture in Iatin on St. Paul's Epistle to the Romans. Abandoning the scholastic interpretation of scripture for a free critical meaning of the text, his lectures had an immediate effect, an effect which caused him problems later.

65 Jtephen, Sir Leslie, and Lee, Sir Sidney, editors, The Dictionary of National Biography, London: Geof $\overline{f r e y}$ Cumberlege, Oxford University Press, 1950, page 778. 
The death of his father in 1505 left colet the master of a vast fortune, and he resolved to devote his money to public purposes. Interested in the enlightened education of children, Colet established in 1509 a school based on the humanist model, with a radically new curriculum. St. Paul's school was a public school of the type which all humanist writers advocated: open to all, placed in the city and not shut away in a monastic precinct and in a building of its own under the control of a public authority, the city company.

Colet called in many humanists to help draw up a new plan of studies, above all others Erasmus. It was the practical necessity of producing textbooks and directions for the teachers which caused Erasmus to lend his extensive knowledge to detailed educational problems. Lily, a married layman, was appointed highmaster and was given living quarters, as was the usher, and $\$ 35$ per year; the usher's salary was $\$ 18$ per year. These rates were two or three times as high as was customary so that the masters might freely teach the 153 boys for whom the school was planned. Books were compiled especially for the school by Colet, Lily and Erasmus. Lily, in the primer which he althored for St. Paul's School, spoke to the reader about the reason for the study of grammar, saying:

$$
\begin{aligned}
& \text { Gramar that intendeth to attain to the under } \\
& \text { standing of the tongues (wherein is contained a } \\
& \text { great treasury of wisdom and knowledge) it should }
\end{aligned}
$$


seem but vaine and lost labor: for so much as it is knowen that nothing can surelie be ended, whose beginning is either feble or faultie: as no building to be perfect whereas the foundation and groundwork is ready to fall and unable to uphold the burthen of the frame. 67

The Latin grammar written by Lily was significantly amended by Erasmus and for this reason was published anonymously. This book was later chosen by Henry VIII to be the sole grammar used in the realm. Writing after the book had been in use for a while, Lily explains the benefit of the prescribed primer and the reason why the plan did not work as effectively as had been hoped:

- . the which hath seemed to manie, verie hard to compass afore time: because that they, who professed this arte of teaching grammar did teach diverse grammars and not one: and if by chance they taught one grammar, yet they did it diversly and so could not do it all best, but also in the mannor of everything. As for the diversity of grammars, it is well and profitably taken away by the kinges Maiesties wisdome, who forseinge the inconvenience and favourablie providing the remedy caused one Kind of Grammar by sundry learned men to be diligently drawn and so to be set out, only everywhere to be taught for the use of learners, and for the hurt on chaunge of schoolmaisters.

The varitie of teaching is diverse yet and always will be: for that every Schoolmaister liketh that he knoweth, and seeth not the use of that he knoweth not, and therefore judgeth that the most sufficient way which he seeth to be the readiest mean and perfectest kind to bring a learner to have a thrugh knowlege therein. 68

Shortly before his death, colet compiled a set of statutes (1518) for the school he had so carefully planned

67 Lily, William, A Short Introduction to Grammar, New York: Scholars Facsimiles \& Reprints, 1945.

68

Ibid. 
and successfully brought into being. He did not set out a detailed curriculum, for he realized that the passage of time and the advancement of knowledge would make change necessary. What the statutes do is to set out his ideas about the teaching of boys, and the intent of his school:

-. I wolde they were taught all way in good litterature, with laten and greke, and good auctors suych as have the veray Romayne eliquence joyned with wisdome, specially Cristyn auctours that wrote theyre wysdome with clene \& chast laten other in verse or in prose, for my entent is by thys scole specially to incresse knowlege and worshipping of god \& oure lorde Crist Jesus \& good Cristen lyff and manners in the children. 69

The boy was to learn grammar by the imitation of good authors, a few only, selected for excellence in expression and morality, for this process "more availeth shortly to get the true eloquent speech than all the traditions, rules and precepts of masters."70 In reading the chosen authors, poets and orators, the boy should "note wisely how they wrote and spake, and study always to follow them, desiring none other rules but their examples."71

In all this reliance upon exercise and imitation at the expense of intensive study of rules and upon close application of a few chosen authors rather than wide

69 Watson, Foster, The English Grammar Schools to 1660 , Iondon: Frank Cass \& Company, Ltd., 1968, pages $373-4$.

70 Nelson, William, A Fifteenth Century Schoolbook, oxford: at the Clarendon Press, 1956, page xx.

71 Ibid. 
reading, Colet is said to show the influence of the essay which Erasmus sent him in 1511 under the title De Ratione Studii. However a passage from the Vulgaria, shows that these ideas were current in England at least a decade before Erasmus' work, and that Erasmus could possibly have gathered these elements of his system of gramnar teaching from England, rather than the other way around:

I have ever had this mind that there is nothing better nother more profitable to bring a man to cunning than to mark such things as is left of good authors, and I mean not all, but the best. And tho (i.e. those) to follow as nigh as a man's mind will give him. And he that doth this beside give himself to exercise, he cannot choose but he must be cunning. 72

In another move away from traditional education, the school was dedicated to the child Jesus, instead of to the cult of the Virgin or Saints. And, instead of praying for the founder as was customary in a chantry school, the chaplain prayed for the children to prosper in good life and good literature. At this mass, whenever the bell in the school "shall knoll to sacring; then all the children in the the school kneeling in their seats shall with lift-up hands, pray in the time of sacring. After the sacring when the bell knolleth again, they shall sit down again to their learning." 73 colet did not want the children's studies to be unduly interrupted by going to masses, thus the direction that they remain at their seats.

72 watson, The English Grammar Schools . . ', op. cit., pages 373-374.

73 Watson, Foster, The Old Grammar Schools, Cambridge: at the University Press, 1916, page 85. 
A school established on such lines could not help but attract attention or criticism. Thomas More wrote to Colet in 1512 ,

I don't much wonder if they are bursting with jealousy of your excellent school. For they see that, just as the Greeks who destroyed barbarian Troy came out of the Trojan horse, so from your school come those who would reprove and overthrow their ignorance. 74

For a time, colet was under a cloud in England. Charges of heresy were brought against him before the Archbishop of Canterbury. Extracts from his sermons showing that he had denounced the worship of images and large episcopal revenues formed the basis of the charges. He was also accused of publishing a paraphrase of the Pater Noster in the vernacular. Colet was saved, however, by the humanist Archbishop Warham, and also attracted the favor of the young King Henry VIII, who was not averse to the school or criticisms of the church.

What was new about colet's school was a clear severing of school teaching from ecclesiastical ritual, and the attempt to permeate education with Christian principle. His was a rational approach to learning; the clearing away of scholastic confusion so that grammar became a tool for the full comprehension of those works of classical and christian writers which incorporated the sum of human wisdom in lay and religious matters. Colet sought to place learning at

${ }^{74}$ Rogers, Elizabeth Frances, St. Thomas More: Selected Letters, New Haven and London: Yale University Press, 1961, page 6 . 
the service of the living, to prepare an individual to live well and to do good in society.

Colet's example was difficult to follow. His association with prominent humanists such as Erasmus and Lily enabled him to obtain specially written texts. In addition, being the only surviving son of a family of twenty-two children, he was able to devote a great deal of family money to the school, allowing him to pay generously for the services of specially trained teachers.

The first highmaster, William Lily, held the position from 1509 until 1522, three years after Colet's death. Lily had been an intimate of colet and was probably one of few masters of St. Paul's who understood completely the ideal envisioned by Colet for his school. Lily is most famous as a grammarian. He entered Magdalen College, Oxford, and after graduating, went on a tour which evenutally took him to Italy. There he studied under Sulpitius and Pomponius Laetus and perfected himself not only in Latin and Greek, but also in the knowledge of classical antiquity.

As stated previously, the grammar book which Lily authored for St. Paul's School was published anonymously. The book which does bear his name is a short Latin syntax with the rules in English, titled Grammatices Rudimental, (1527). Considering the brevity of this work, the fame which Lily enjoyed as a grammarian is remarkable. 75

${ }^{75}$ Dictionary of National Biography, Vol. XI, page 1144. 
The second highmaster, John Ritwise (1522-32) was married to Lily's daughter and was surmaster for four or five years. He gave, at first, as much satisfaction as Highmaster as he had as Surmaster, and the school so prospered under his rule that in 1525 the statutory number of 153 scholars was exceeded. He was warned by the Mercer's Company that all who were not Londoners should be sent away. In December of both 1525 and 1526, Ritwise was called up before the Mercers and told that he was not doing his duty by the school and was warned to conduct himself with more diligence to his duty. He seemed to have taken the warnings to heart for a time, but he suffered a relapse of negligence and in December 1531, he was asked "to avoid from the said room of schoolmaster"76 the following midsummer. It appears that he was granted a reprieve, however, for in November 1532 he was reported not to have mended his ways but was getting worse, and was finally "utterly expelled amoved and put furth of the same rome of scole maistershippe."77

It seems that the following years were ones of continual headaches for the governing body of the school as they attempted to maintain the quality of education which Colet had wanted. It must be admitted, however, that many of the problems associated with the highmasters stemmed from

$76_{\text {MCDonnell, Sir Michael, Annals of St. Paul's School, }}$ London, 1959, page 65 .

77 Ibid. 
the leniency of the Mercer's Company in dealing with the highmasters. For example, of the six highmasters who served between the tenures of William Lily and Richard Mulcaster, only one, William Malym (1573-81) was not consistently in trouble with the governing board. Yet, concerning the remaining five, the board was content to put up with years of warning the master until he either died (one case), retired (one case), or was asked to leave (three cases). ${ }^{78}$ Richard Mulcaster, the last highmaster to serve st. Paul's during Elizabeth's reign, enjoyed an almost flawless relationship with the governors of the school for his first $71 / 2$ years as highmaster. As it had been during his twenty-five year tenure at Merchant Taylor's School, the quality of his teaching was very high and the school prospered. Relations with the governing board became somewhat strained, however, due to Mulcaster's continual need of money. He had a history of advances and loans to augment his salary and he was guilty at least twice of selling his nominations to masterships in the school, an action which was not looked upon favorably by the board. He retired in 1608, voluntarily, due to advanced age. ${ }^{79}$

Generally, schools continued to be established on the old model, using the same methods of expounding grammar

78 MCDonne11, op. cit., pages 58-183.

79 Ibid., pages 176-177. 
rules and learning by rote. As time went on, St. Paul's found it difficult to locate good schoolmasters, as the average one lacked all the necessary intellectual training to approach the classics as literature with grammar as a subsidiary.

The humanist ideal of educating the young in virtue and piety for the service of the commonweal was held by many. Ascham and Elyot, however, concerned themselves particularly with fashioning a program of education that might regenerate the decadent aristocracy of England. They did not approve of the change taking place whereby commoners of outstanding talent and character were succeeding to public offices traditionally belonging to men of noble birth and ancient wealth.

In this vein, Hugh Latimer (1485-1555) wrote: "For why are not the noblemen and young gentlemen of England so brought up in knowledge of God and learning that they may be able to execute offices in the commonweal?"80 "I trow there is a court of Wards, why is there not a school for the wards, as well as there is a court for their lands?"81. These were points which starkey had raised when advocating specially constituted schools, leaving the universities to the scholars and the church. Latimer continued, "Or why are

80 Kelso, Ruth, Doctrine of the English Gentleman in the Sixteenth Century, Urbana, IIIinois: University of Illinois Press, 1929, page 114.

81 Hurstfield, Joel, The Queen's Wards, London: Longmans, Green \& Company, 1958, page 25. 
they not sent to universities that they may be able to serve the king when they come to age?" 82 He thought that the only reason that noblemen were not chosen for high offices was because they had not been brought up in learning. His remedy was to appoint teachers and schoolmasters and give them stipends worthy of their situation, so they would bring the students up in grammar, logic, rhetoric, philosophy and the word of God.

The universities had always attracted the younger sons of nobles who were destined for the church, but they no longer looked to the church since the days of the princely prelates had passed. They looked for the same kind of career as before, but no longer saw entry to the church as the way to it, since key posts in government and administration were now held by laymen qualified in Common Law. It was gentlemen's heirs who studied for "knowledge and pleasure" who set the new tone. Ascham wrote to Cranmer in 1547, lamenting that Cambridge was now full of mere boys, as students being admitted were for the most part only the sons of rich men, and as such never intended to pursue their studies to that degree as to arrive at an eminent proficiency and perfection of learning, but only the better to qualify themselves for some places in the state, by a slighter and more superficial knowledge. This was detrimental to learning, since the "drones" kept out the poorer students whose time was wholly spent in good studies.

82 Kelso, .. the English Gentleman, op. cit., page 114. 
Sir Humphrey Gilbert sketched the basis of a new education on the lines of an academy to meet the needs of the landed class which the public and grammar schools failed to supply. The project of 1572 was titled The erection of an Academy in London for the education of Her Majesty's Wards and others the youth of Nobility and Gentlemen. His was not a new idea, for Latimer had earlier called attention to the need for a school for wards, and a scheme similar to. Gilbert's had been proposed by Sir Nicholas Bacon in 1561. The idea of a national academy recurs throughout the seventeenth century.

The purpose of Gilbert's academy was to provide education for the royal wards, the orphans of the nobility who, farmed out as was the custom among the nobles often suffered from the indifference of their guardians, and also for the children of the gentry in general. The advantages of such a scheme are best stated in Gilbert's words:

- . by erecting this Achademie, there shalbe heareafter, in effect, no gentleman within this realme but good for some what, Wheareas now the most parte of them are good for nothinge. And yet therby the Courte shall not only be greatly encreased with gallant gentlemen, but also with men of vertue, wherby your Majesties and Successors courtes shalbe for ever, in steade of a Nurserie of Idleness, become a most noble Achademy of chivalric pollicy, and philosophie to your greate fame.. .83 .

The curriculum set out by Gilbert included all that moralists, divines, martialists, fencing masters and heralds,

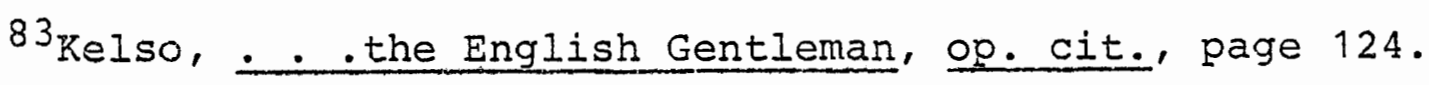


as well as pedagogues prescribed for the attainment of perfection. First on his list were logic and rhetoric, since they were held particularly important for the gentleman who must speak in Parliament, council or embassy. The list included also arms, manly exercises, Latin, modern languages, practical mathematics and natural philosophy. Though often talked about, no courtly academies were ever established and the traditional methods of educating the nobility continued, although with the curricular content expanded. As the sixteenth century progressed, however, the young nobility began increasingly to attend the same schools as the "cream of the common," which went far in creating a common outlook. 
CHAPTER X

\section{ENGLISH RENAISSANCE SCHOOLS IN REALITY}

While before the Renaissance it was the sons of the non-nobles who received a grammar school education, during the second half of the sixteenth century, the trend was reversed. By 1580, there was a greater demand for education and an increase in the number of schools. However, necessity acted as a brake on the educational aspirations of many, as parents might lack money and need the child at home, or when there was no school nearby, they might not be able to afford to send the child out. The really poor did not even begin to press on the established grammar school as they often were impressed into work at an early age or were apprenticed. Grammar schools were also out of reach of the laborer earning $3 \mathrm{~d}$. per day or the poor husbandman who needed his children at home. In addition, there was the problem of finding money to equip a boy for school. "Free" schools had many incidental fees plus the cost of books, clothing and voluntary gifts.

A large proportion of the population was excluded from the benefits of grammar schools, leaving as the main candidates for entry the sons of the more considerable yeoman farmers and burgesses, the country gentry and professional men, including ministers of the church. Scholarships were often attached to school foundations, either endowed at a particular college, or held by the governors to aid students 
going on to a university. However, relatively few funds were available to aid the poor boy to attend and remain in school. It seems that only those going on to the university stayed on at the grammar school past the age of fourteen when apprenticeship began, while others might have spent . only a year or two at school. It was bitterly complained that poor scholars were deprived of scholarships while the rich men's sons who got them studied little.

The usual age to enter grammar school was at six or seven. More often than not, qualifications of literacy were imposed as a condition of entry. The most immediate and most important purpose of learning the arts of reading and writing was to enable the child to master the elements of his religious life, the Lord's Prayer, the Ten Commandments, the Creed, and the Seven Sacraments. The Primer served as both an elementary reader and the first book of religious instruction.

Tudor sovereigns and their advisors were well aware of the importance of early religious training and made provision accordingly. Educationalists too, were recognizing the importance of a sound grounding in the elements of the English language, not merely as part of the religious education, nor as simply a precursor to the grammar course, but as part of a wider movement which sought to elevate the English language as a medium of literary expression.

The child's study of grammar fell into two fairly welldefined parts, supervised in larger schools by the usher 
and master respectively. Under the usher, the boy's time would be spent learning the elementary rules of grammar, drill and repetition being the dominant methods used. After having mastered these rules, the student was made to apply the knowledge by constructing sentences - the "making of Latins" or the "making of vulgars," and thus began to acquire vocabulary. Incidently, this procedure was soundly denounced by many humanists, including Erasmus, Vives and Ascham, who preferred the method of double translation.

Samples of "vulgars" which are available to the modern historian give a good picture of life in former times, speaking of food, wearing apparel, beatings, life in London, play, and so on. Examples follow of sentences to be translated into Latin, taken from A Fifteenth Century Schoolbook. 84

As I hauntede ale howses and wyn taverns, I have spend all the money that I hade in my purse." (No. 33, page 9)

"Wolde to gode that I hade spede the yeres in goode connyng that I have loste lewdely in evyle grammer." (No. 80, page 20)

"Yff ther be eny of my felows that love not my maister, I confesse that I am on." (No. 122, page 30)

When the rudiments were mastered, the student would proceed with the master to the real end of these exercises: Latin composition, i.e. the writing and speaking of themes, letters, verses and orations in imitation of classical authors whose works he would read.

${ }^{84}$ Nelson, op. cit., pages $33,80,122$. 
Erasmus recommended the concurrent study of Greek and Latin because of the body of knowledge made available and because learning one would aid in learning the other. Yet, it is unlikely that anything more than lip service was paid to Greek in the general run of grammar schools. Statutes for schools state that Greek should be taught if there is someone available who can teach it, and it was not until the 1560 's that Greek was specified in statutes. There is little evidence that Hebrew was taught in any more than a small number of schools, and it was rarely prescribed in statutes.

The traditional picture of an English grammar school is as a place where boys were forbidden to speak any other language than Latin - not even their own. "Boys were not taught Latin, they were taught in Latin, they were not allowed to utter a single vernacular word whilst at school. - . 85 Yet, this must have been very difficult to enforce. In addition, in the teaching of Latin grammar, the use of English was not only a necessary expedient, but recognized by masters to be of positive educational value, though English as a separate subject was never taught. The English language coming into its own was partly the result of the Reformation. A vernacular Bible was produced, and in keeping with the growing feeling of national pride, the use of the vernacular was seen as another way of indicating

${ }^{85}$ Charlton, op. cit., page 119. 
England's emancipation from papal subservience. As the sixteenth century progressed, more evidence points to the instruction of grammar in English and the increasing insistence that the writing of good English must accompany the writing of good Latin. The prohibition against speaking English in Tudor schools must be put into context and interpreted as referring to those hours of school life devoted to learning Latin, and not as an absolute prohibition. 86

Erasmus and Vives emphasized that the end of education should be knowledge and understanding, for to read and not understand is the waste of all good learning. It follows, then, that the understanding and use of English must always proceed with the learning of Latin. English material can be dictated to the children to be translated into Latin and back again. Thus they learn to spell English and exercise writing as well.

Going along with the increased use of English in the schools was the influence of English in promoting popular education. A stream of books in the vernacular had become a flood by the end of the century, giving the ordinary citizen an established share in the spread of knowledge. By the 1580's, most of the major works of classical literature, including educational writings, were available in English. Scholars called this a cheapening of knowledge, but the translators stood their ground. This great outpouring of translations reflects two aspects of education in Renaissance 
England. First, their work was an expression of the claim for the common man to understand the content and ideas of literature provided that the language barrier was removed and the text was presented in the vernacular. Secondly, this indicated the belief that learned men should play their part in the task of the popularizing and dissemination of knowledge. The Renaissance was an optimistic time in that this claim was not only recognized but it was firmly believed that education, widely spread, would produce a better society.

What most contributed to the quality and kind of education which went on in grammar schools of Renaissance England was the quality of masters who taught in them. Erasmus' texts were widely recommended and used, but Englishmen went above all to Vives. His insistence on the need to observe the child and adapt both aim and method to his needs, his call for a humane relationship between master and pupil, his advocacy of the vernacular in the early stages of education, and his thoroughly humanistic approach to the classics produced much of the theoretical basis for sixteenth century innovations in English education.

That was the positive side. Unfortunately, the practice in the majority of schools, particularly in the smaller grammar schools, showed a gloomier face. Much of the humanist plea for a cheerful atmosphere was submerged by a brutality toward the boys which not only reflected the violence of personal'life which remained a part of the Tudor 
scene, but also found new sanction in the Calvinist insistence of the essential depravity of man.

Harsh though this discipine was, it was a means to the great end of all education, the development of a strong moral character. The boy may have been driven and whipped into much barren knowledge, but this process was not carried on for the pleasure derived from the process itself. It was conscientiously believed that in mastering Latin, he was fitting himself for Iife and developing character. The punishments he received were to help him in his efforts by making unstudious habits unpleasant. 87

There are other factors which must also be taken into account. While the state had much to say on the moral and religious qualifications of the master and usher, little was said about their intellectual preparation. Thus, no uniform standard of academic qualification was imposed to insure a high quality education. In addition, the teaching staff of the average Elizabethian Grammar School was very small often only a master, sometimes aided by an usher. With the master and usher sharing between them the whole workioad of the upper and lower schools, classes were large and discipline was inevitably fierce. And, the pay being miserably small, the quality of teachers was correspondingly low.

87Stowe, A: R. Monroe, English Grammar Schools in the Reign of Elizabeth, New York, 1908, page 145 . 
CHAPTER XI

CONCLUSION

At first sight, it would seem that the Renaissance produced the great age of English grammar schools which, surviving the shock of the Reformation, enjoyed royal patronage, were supported by enlightened and learned followers and benefitted from schoolmasters who had assimilated the educational ideals of humanism. All this was taking place in a time of demographic growth and increased urbanization which would provide increased demand for grammar schools. Yet, such a picture is incomplete and misleading and describes the prescription rather than actual practice. It ignores the uniformity imposed on schools by successive sovereigns for political and religious reasons, producing a stifling effect on creative and progressive education.

Humanist ideas did not produce a nation-wide system of humanist education, but did manage to leave a strong impression on English education, especially on English private boys" schools, the "great public schools." Although in practice many aspects of education were unmoved by humanist theories, the many areas influenced by humanism were changed forever. The vernacular became established as a literary medium, much to the benefit of the common man; education of the upper class, the ruling class, came to be viewed as not only desirable, but necessary; attitudes toward the ed- 
ucation of women were altered for a time, as were methods used in teaching children. A fact of greater importance, however, is that humanist ideals were taken up and absorbed into ways of thought, to have an even broader use in the service of contemporary needs. 


\section{BIBILIOGRAPHY}

Primary Sources

Ascham, Roger, The Scolemaster, John E. R. Mayor, Editor, London: Bill and Daldy, 1863.

Ascham, Roger, The Schoolmaster, Lawrence V. Ryan, editor, New York: Cornell University Press, 1967.

Castiglione, Count Baldassare, The Courtier, translated by Sir Thomas Hoby, 1561, New York: AMS Press, Inc., 1967.

Lily, William, A Short Introduction to Grammar, New York: Scholars Facsimiles \& Reprints, 1945.

More, Sir Thomas, Utopia, translated by Ralph Robinson, London: Macmillan and Company Itd., 1908.

Mulcaster, Richard, Positions, abridged and edited by Richard I. DeMolen, New York: Teachers College Press, 1971 .

Sturtz, Edward S. J. and Hexter, J. H., editors, The Complete Works of St. Thomas More, Vol. 4, New Haven and London, Yale Univ. Press, 1965, pages 131-133.

Three Primers Put Forth in the Reign of Henry VIII, Oxford: at the University Press, 1834 .

Vives, Juan Luis, Introduction to Wisdom, edited by Marian L. Tobriner, New York: Columbia University, 1968.

Wright, Louis B., Editor, Advice to a Son, Ithaca, New York: Corneil University Press, 1962.

- Editor, Life and Letters in Tudor and Stuart England, Ithaca, New York: Cornell University Press, 1958. 


\section{BIBLIOGRAPHY}

\section{Secondary Sources}

Adams, Robert P., The Better Part of Valor, Seattle, University of Washington Press, 1962,

Adamson, John William, The Illiterate Anglo-Saxon and Other Essays on Education, Medieval and Modern, Cambridge: at the University Press, 1946.

Ames, Russell, Citizen Thomas More and His Utopia, Princeton, New Jersey: Princeton University Press, 1949.

Artz, Frederick B., The Mind of the Middle Ages, AD 200-1500, New York: Alfred A. Knopf, 1966.

Basset, Bernard, S. J., Born for Friendship - The Spirit of Sir Thomas More, New York: Sheed and Ward, 1965.

Beck, Robert Holmes, A Social History of Education, Englewood Cliffs, New Jersey, Prentice-Hall, 1965.

Berry, B. M., "The First English Fediatricians and Tudor Attitudes Toward Childhood," Journal of the History of Ideas, 35: 561-77, October 1974.

Casperi, Fritz; Humanism and the Social Order in Tudor England, New York, Columbia University, 1954.

Charlton, Kenneth, Education in Renaissance England, London, Routledge and Kegan Paul, Ltd., 1965.

Colish, Marcia L., "Mime of God: Vives on the Nature of Man," Journal of the History of Ideas, 23: 3-20, January 1962 .

Cowie, I. W., "More's House in Chelsea," History Today, 26: $118-24$, February 1976.

Curtis, Mark H., Oxford and Cambridge in Transition 1558-1642, oxford, at the Clarendon Press, 1959.

Demolen, Richard I., "Richard Mulcaster and the Profession of Teaching in Sixteenth Century England," Journal of the History of Ideas, 35: 121-9, January $197 \overline{4}$.

Dickens, A. G., The English Reformation, New York: Schocken Books, 1964 . 
Dodd, A. H., Iife in Elizabethian England, edited by Peter Quenneli, London, B. T. Batsford, Itd., 1961.

Donner, H. W., Introduction to Utopia, Uppsala, Sweden: Sidgwick and Jackson, Itd., 1945.

Elton, G. R., England Under the Tudors, Iondon, Methuen and Company, Ltd., 1955 .

Ferguson, Arthur B., The Articulate Citizen and the English Renaissance, Durham, North Carolina, Duke University Press, 1965.

Froude, J. A., Iife and Letters of Erasmus, New York: Charles scribner's Sons, 1894 .

Gray, H. H., "Renaissance Humanism: The Pursuit of Eloquence," Journal of the History of Ideas, 24: 497-514, October 1963.

Hattaway, M., "Paradoxes of Solomon: Learning in the English Renaissance," Journal of the History of Ideas, 29: 299-530, October 1968.

Huizinga, Johan, Erasmus and the Age of Reformation, New York: Harper and Brothers, 1957.

Hurstfield, Joel, The Queen's Wards, London: Longmans, Green and Company, 1958.

Jarrett, Bede O. P., Social Theories of the Middle Ages, 1200-1500, London: Ernest Benn Limited, 1926 .

Jordan, W. K., Edward VI: The Threshold of Power, Cambridge: Harvard University Press, 1970. The Charities of Rural England 1480-1660, New York: Russell Sage Foundation, 1961. , Philanthropy in England 1480-1660, New York: Russell sage Foundation, 1959.

Kelso, Ruth, Doctrine for the Lady of the Renaissance, Urbana: University of Illinois Press, 1956.

, Doctrine of the English Gentleman in the Sixteenth Century, Urbana: University of IIIinois Press, 1929 .

Lawson, John, Medieval Education and the Reformation, London: Routledge and Kegan Paul, Ltd., 1967. 
Leff, Gordon, Paris and oxford Universities in the 13th and 14 th Centuries, New York: John Wiley and Sons, 1968.

Martienssen, Anthony, Queen Katherine Parr, London: Secker and Warburg, 1973 .

McConica, James Kelsey, English Humanists and Reformation Politics Under Henry VIII and Edward VI, Oxford: at the Clarendon Press, 1965.

McDonnell, Sir Michael, Annals of St. Paul's School, London, 1959 .

McLean, Antonia, Humanism and the Rise of Science in Tudor England, Iongon: Heinemann Educational Books Ltd., 1972 .

Nelson, William, A Fifteenth Century Schoolbook, Oxford: at the Clarendon Press, 1956.

Orme, Nicholas, English Schools in the Middle Ages, London: Methuen and Company, Ltd., 1973.

Parry, A. W., Education in England in the Middle Ages, London, W. B. Clive, 1920 .

Phillips, Margaret Mann, The "Adages" of Erasmus - A Study With Translations, Cambridge: at the University Press, 1964 .

Power, Eileen, Medieval English Nunneries c. 1275 to 1535 , New York: Bible and Tanner, 1964.

Rait, Sir Robert Sangster, Life in the Medieval University, Cambridge University Press, 1912.

Reynolds, E. E., The Field is Won - The Life and Death of Saint Thomas More, Milwaukee, The Bruce Publishing Company, 1968 .

University Press, 1965 .

Rogers, Elizabeth Frances, editor, St. Thomas More: Selected Letters, New Haven and London: Yale University Press, 1961 .

Ryan, Lawrence V., Roger Ascham, Stanford, California: Stanford University Press, 1963.

Simon, Joan, The Social Origins of English Education, London, Routledge and Kegan Paul, Ltd., 1970. 
Education and Society in Tudor England,

Cambridge: at the University Press, 1967.

Smith, C. I., "Some Ideas on Education Before Locke," Journal of the History of Ideas, 23: 403-6, July 1962 .

Stephen, Sir Leslie, and Lee, Sir Sidney, editors, The

Dictionary of National Biography, London: Geoffrey Cumberlege, Oxford University Press, 1950, Vols. VI, XI.

Stowe, A. R. Monroe, English Grammar Schools in the Reign of Elizabeth, New York: 1908.

Surtz, Edward, S. J., The Praise of Pleasure - Philosophy Education and Commumism in More's Utopia, Cambridge: Harvard University Press, 1957.

Watson, Foster, The English Grammar Schools to 1660, Iondon: Frank Cass \& Company, Itd., 1968.

- The Old Grammar Schools, Cambridge: at the University Press, 1916.

- Vives: On Education, Cambridge: at the University Press, 1913.

Wood, Norman, The Reformation and English Education, London: George Routledge \& Sons, Ltd., 1931.

Woodward, William Harrison, Desiderius Erasmus Concerning the Aim and Method of Education, New York: Columbia University, 1964 .

, Studies in Education During the Age of the Renaissance, 1400-1600, New York: Columbia University, 1967. 